UNIVERSIDADE FEDERAL DE JUIZ DE FORA

PÓS-GRADUAÇÃO EM CIÊNCIAS FARMACÊUTICAS

Daniel da Silva Torres

Avaliação do potencial de auronas na terapia da esquistossomose in vitro e em modelo murino

Juiz de Fora

2018 
Daniel da Silva Torres

Avaliação do potencial de auronas na terapia da esquistossomose in vitro e em modelo murino

Dissertação de Mestrado do curso de PósGraduação em Ciências Farmacêuticas: Área: Produtos Naturais Bioativos, da Universidade Federal de Juiz de Fora, para obtenção do grau de Mestre em Ciências Farmacêuticas.

Orientadora: Prof. Dra. Priscila Faria Pinto 
Ficha catalográfica elaborada através do programa de geração automática da Biblioteca Universitária da UFJF, com os dados fornecidos pelo(a) autor(a)

Torres, Daniel da Silva .

Avaliação do potencial de auronas na terapia da esquistossomose in vitro e em modelo murino / Daniel da Silva Torres. -- 2018.

$58 \mathrm{f}$. : il.

Orientadora: Priscila Faria Pinto

Dissertação (mestrado acadêmico) - Universidade Federal de Juiz de Fora, Faculdade de Farmácia e Bioquímica. Programa de Pós-Graduação em Ciências Farmacêuticas, 2018.

1. Esquistossomose. 2. Auronas. 3. Atividade esquistossomicida. I. Pinto, Priscila Faria, orient. II. Título. 


\title{
Avaliação do potencial de auronas na terapia da esquistossomose in vitro e em modelo murino
}

\author{
Daniel da Silva Torres
}

\section{ORIENTADORA: Priscila Faria Pinto}

Dissertação de Mestrado submetida ao Programa de Pós-Graduação em Ciências Farmacêuticas, da Universidade Federal de Juiz de Fora - UFJF, como parte dos requisitos necessários à obtenção do título de Mestre em Ciências Farmacêuticas.

Aprovada em 26/09/2018

marcella moctins terra

Prof.(a) Dr.(a) Marcella Martins Terra

boumai elle ro de 9. Anogás

Prof.(a) Dr.(a) Danielle Maria de Oliveira Aragão

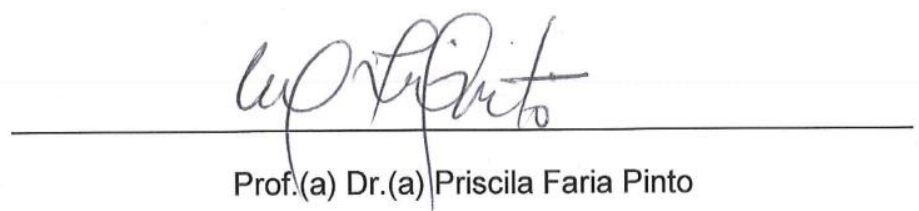




\section{AGRADECIMENTOS}

À minha amada família por todo apoio e amor incondicional.

Aos meus amigos de longa data e aos novos amigos que fiz em Juiz de Fora.

À população juz-forana por ter me acolhido em seus espaços, por ter me mostrado sua cultura e me feito um baiano um "cadin" mineiro.

Aos colegas do Laboratório de Estrutura e Função de Proteínas pelas parcerias nos trabalhos e por todo o companheirismo.

Aos colegas do Instituto René Rachou-Fiocruz Minas, em especial à equipe do Laboratório de Esquistossomose por ter nos acolhido e ter dado todo o suporte para a realização deste trabalho.

À UFJF da qual eu tenho muito orgulho de ter sido aluno.

À minha orientadora, professora Priscila Faria, por me guiar nesse percurso árduo de formação intelectual, pelas palavras de apoio e incentivo em tantos momentos difíceis e por se tornar um referencial de profissional para mim. Meu muito obrigado! 


\section{RESUMO}

A esquistossomose é uma parasitose causada pelo helminto Schistosoma mansoni que afeta em torno de 240 milhões de pessoas no mundo. A terapia farmacológica para essa doença ainda é muito restrita, sendo importante a busca continua por novos fármacos. O objetivo desse trabalho foi avaliar o potencial farmacológico de três auronas sintéticas em modelos de esquistossomose in vitro e in vivo. $\mathrm{Na}$ avaliação in vitro, casais de vermes adultos foram expostos às drogas $(25 \mu \mathrm{M})$ e às sondas fluorescentes que marcam poros de membrana (FITC-Dextrans) e formação de autofagossomos (monodansylcadaverine). Comparados aos grupos-controles, observou-se uma intensificação da marcação em todos os grupos tratados com as drogas, sugerindo que todas as três auronas, de algum modo, intensificam a formação de poros e de autofagossomos nos vermes. Adicionalmente, avaliou-se o efeito de inibição das auronas sobre a apirase da batata, uma isoforma de NTPDase estruturalmente relacionada com as isoformas presentes nos parasitos. Nesses ensaios, LS26 inibiu parcialmente as atividades ATPásica (em 15, 12 e 47\%, nas respectivas concentrações $0,1 \mathrm{mM}, 0,001 \mathrm{mM}$ e 0,0001mM) e ADPásica (em 21,5\%, na concentração de $0,001 \mathrm{mM}$ ), o que torna relevante a investigação do seu potencial inibidor frente as NTPDases de S. mansoni. Nos ensaios in vivo, LS26 e LS29 reduziram a carga global parasitária nos animais tratados (em $56.20 \%$, para tratados com LS26 $50 \mathrm{mg} / \mathrm{Kg}$, em duas doses; e $57,61 \%$, para tratados com LS29 50 $\mathrm{mg} / \mathrm{Kg}$, em duas doses, comparados ao grupo-controle não tratado). Ainda, LS26 e LS29 foram capazes de aumentar o deslocamento parcial dos vermes das veias mesentéricas para os vasos hepáticos e de interferir na cinética de desenvolvimento dos ovos. Na avaliação do nível de peroxidação lipídica no fígado dos animais tratados com as auronas, não foram observadas alterações. Os resultados apontam a necessidade de estudos adicionais de farmacocinética e farmacodinâmica para um melhor conhecimento dos mecanismos de ação de LS26 e LS29, para sua utilização em uma formulação para o tratamento da esquistossomose.

Palavras-chave: esquistossomose, auronas, atividade esquistossomicida. 


\begin{abstract}
Schistosomiasis is a disease caused by the helminth Schistosoma mansoni that affects about 240 million people in the world. Pharmacological therapy for this disease is still very restricted, and a search for new drugs is important. The aim of this work was to evaluate the pharmacological potential of three synthetic aurones in schistosomiasis models (in vitro and in vivo). In in vitro assays, worms were exposed to drugs $(25 \mu \mathrm{M})$ as well as probes to investigate membrane permeability (FITCDextrans) and autophagosome formation (monodansylcadaverine). Compared at groups-controls, there was an increase in marking in all groups treated with the drugs, suggesting that all three aurones somehow intensify the formation of pore and autophagosomes in the adult worms. Additionally, the effect of inhibition of the aurones on potato apyrase, an isoform of NTPDase structurally related to the isoforms present in the parasites. In these assays, LS26 partially inhibited ATPase activity (at 15, 12 and $47 \%$, in the $0.1 \mathrm{mM}, 0.001 \mathrm{mM}$ and $0.0001 \mathrm{mM}$ bands) and ADPasic activity (at $21.5 \%$, at $0.001 \mathrm{mM}$ concentration), which indicates the relevance of further investigation of its potential as an inhibitor of NTPDases of $S$. mansoni. In the in vivo assays, LS26 and LS29 reduced the parasitic load in the treated animals (56.20\% for those treated with LS26 $50 \mathrm{mg} / \mathrm{kg}$ in two doses; and $57.61 \%$ for those treated with LS29 $50 \mathrm{mg} / \mathrm{kg}$, in tow doses, compared to the untreated control group). Furthermore, LS26 and LS29 caused an increase in the partial displacement of worms from the mesenteric veins to the hepatic vessels and they also interfered in the kinetics of egg development. In the evaluation of the level of lipid peroxidation in the liver, no significant difference was found between animals who were treated and untreated with LS26 and LS29. Finally, we reinforced that additional pharmacokinetic and pharmacodynamic studies should be done for a better understanding of the mechanisms of action of LS26 and LS29 for use in a formulation for the treatment of schistosomiasis
\end{abstract}

Key words: schistosomiasis, aurones, schistosomicidal activity. 


\section{LISTA DE ILUSTRAÇÕES}

Figura 1 - Distribuição da esquistossomose segundo percentual de positividade em inquéritos coproscópicos................................................. 15

Figura 2 - Ciclo biológico do Schistosoma mansoni..................................... 16

Figura 3 - Estrutura química do praziquantel e oxamniquina.......................... 18

Figura 4 - Núcleo fundamental dos flavonoides......................................... 20

Figura 5 - Estrutura básica das auronas.................................................. 21

Figura 6 - Estrutura química das auronas LS23, LS26 e LS29..................... 22

Figura 7 - Marcação de autofagossomos em vermes adultos de Schistosoma mansoni pela sonda fluorescente monodansylcadaverine após exposição à LS23 ou veículo por 24 horas

Figura 8 - Marcação de poros (integridade/permeabilidade) no tegumento de vermes adultos de Schistosoma mansoni pelas sondas fluorescentes FITC- Dextrans após exposição à LS23 ou veículo por 24 horas

Figura 9 - Marcação de autofagossomos em vermes adultos de Schistosoma mansoni pela sonda fluorescente monodansylcadaverine após exposição à LS26 ou veículo por 24 horas.

Figura 10 - Marcação de poros (integridade/permeabilidade) no tegumento de vermes adultos de Schistosoma mansoni pelas sondas fluorecentes FITC- Dextrans após exposição à LS26 ou veículo por 24 horas

Figura 11 - Marcação de autofagossomos em vermes adultos de Schistosoma mansoni pela sonda fluorescente monodansylcadaverine após exposição à LS29 ou veículo por 24 horas.

Figura 12 - Marcação de poros (integridade/permeabilidade) no tegumento de vermes adultos de Schistosoma mansoni pelas sondas fluorecentes FITC- Dextrans após exposição à LS29 ou veículo por 24 horas

Gráfico 1 - Efeito do veículo sobre as atividades ATPásica e ADPásica da NTPDase de Solanum tuberosum.

Gráfico 2 - Efeito da droga LS23 sobre as atividades ATPásica e ADPásica da NTPDase de Solanum tuberosum. 
Gráfico 3 - Efeito da droga LS26 sobre as atividades ATPásica e ADPásica da NTPDase de Solanum tuberosum.

Gráfico 4 - Efeito da droga LS29 sobre as atividades ATPásica e ADPásica da NTPDase de Solanum tuberosum.

Gráfico 5 - Distribuição da carga parasitária nos grupos de animais não tratados, tratados com praziquantel (PZQ) e grupos tratados com a droga LS26 em diferentes esquemas terapêuticos.

Gráfico 6 - Distribuição da carga parasitária nos grupos de animais não tratados, tratados com praziquantel (PZQ) e grupos tratados com a droga LS29 em diferentes esquemas terapêuticos.

Gráfico 7- Níveis de malondialdeído em homogenato de fígado de animais submetidos à infecção com Schistossoma mansoni

Tabela 1 - Taxas de recuperação dos vermes adultos de Schistosoma mansoni, expressas em média e desvio padrão (DP), e distribuição percentual, em relação à média, encontradas no mesentério e fígado dos grupos de animais não tratados, tratados com praziquantel (PZQ) e grupos tratados com a droga LS26 em diferentes esquemas terapêuticos.

Tabela 2 - Taxas de recuperação dos vermes adultos de Schistosoma mansoni, expressas em média e desvio padrão (DP), e distribuição percentual, em relação à média, encontradas no mesentério e fígado dos grupos de animais não tratados, tratados com praziquantel (PZQ) e grupos tratados com a droga LS29 em diferentes esquemas terapêuticos.

Tabela 3 - Distribuição percentual dos ovos viáveis encontrados nos fragmentos de intestino delgado de animais infectados por Schistosoma mansoni submetidos a diferentes tratamentos com LS26 ou PZQ e classificação do estado do oograma.

Tabela 4 - Distribuição percentual dos ovos viáveis encontrados nos fragmentos de intestino delgado de animais infectados por Schistosoma mansoni submetidos a diferentes tratamentos com LS29 ou PZQ e classificação do estado do oograma. 


\section{LISTA DE ABREVIATURAS E SIGLAS}

$\begin{array}{ll}\text { ADP } & \text { Adenosina difosfato } \\ \text { ATP } & \text { Adenosina trifosfato } \\ \text { BHT } & \text { 2,6-bis(1,1-dimetiletil)-4-metilfenol } \\ \text { CEUA } & \text { Comitê de Ética para o Uso de Animais } \\ \text { DMSO } & \text { Dimetilsulfóxido } \\ \text { DNDi } & \text { Drugs for Neglected Diseases initiative } \\ \text { FITC } & \text { Isotiocianato de fluoresceína } \\ \text { MDA } & \text { Malondialdeído } \\ \text { MOPS } & \text { Ácido 3-N-morfolino-propanosulfônico } \\ \text { Meio-RPMI } & \text { Meio-Roswell Park Memorial Institut } \\ \text { NIPPAN } & \text { Núcleo de Identificação e Pesquisa de Princípios Ativos Naturais } \\ \text { OMS } & \text { Organização Mundial da Saúde } \\ \text { Pi } & \text { Fostato inorgânico } \\ \text { PZQ } & \text { Praziquantel } \\ \text { SmATPDase } & \text { Abreviação para ATP difosfohidrolase de Schistosoma mansoni } \\ \text { SRAT } & \text { Substâncias Reativas do Ácido Tiobarbitúrico } \\ \text { SRATB } & \text { Teste das Substâncias Reativas do Ácido Tiobarbitúrico } \\ \text { TBA } & \text { Ácido tiobarbitúrico } \\ \text { TRIS } & \text { Trishidroximetilaminometano } \\ \text { UFJF } & \text { Universidade Federal de Juiz de Fora }\end{array}$


1 INTRODUÇÃO

1.1 CONSIDERAÇÕES SOBRE DOENÇAS NEGLIGENCIADAS E

ESQUISTOSSOMOSE.

1.2 ESQUISTOSSOMOSE MANSONICA: CICLO BIOLÓGICO E TERAPIA

FARMACOLÓGICA

1.3 CONSIDERAÇÕES SOBRE FLAVONOIDES E AURONAS

1.4 CONSIDERAÇÕES SOBRE NTPDASES E SUA RELEVÂNCIA NA

ESQUISTOSSOMOSE COMO ALVO TERAPÊUTICO.

1.5 ESQUISTOSSOMOSE E PEROXIDAÇÃO LIPÍDICA................................ 24

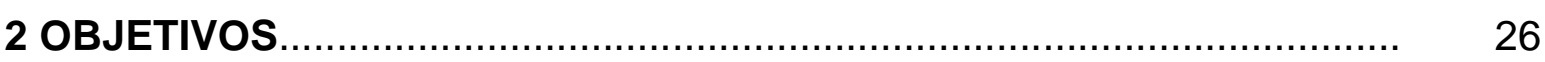

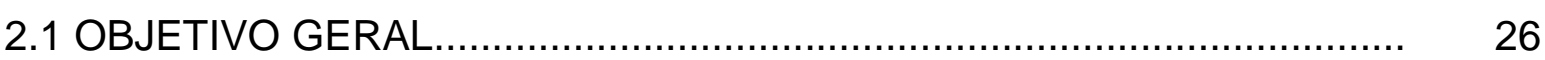

2.2 OBJETIVOS ESPECÍFICOS............................................................... 26

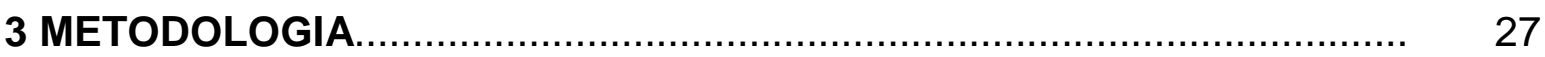

3.1 DELINEAMENTO EXPERIMENTAL E LOCAL DE PESQUISA................ 27

3.2 OBTENÇÃO DAS AURONAS................................................................ 27

3.3 INFECÇÃO E CICLO......................................................................... 27

3.4 ENSAIOS DE INIBIÇÃO DA ATIVIDADE ENZIMÁTICA DA APIRASE

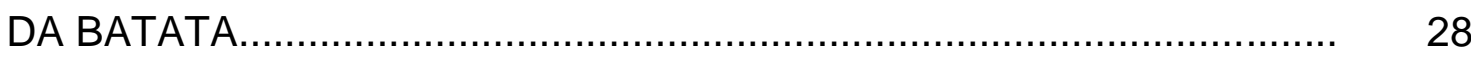

3.5 AVALIAÇÃO IN VITRO DO EFEITO DAS AURONAS SOBRE OS

VERMES ADULTOS DE SCHISTOSOMA MANSONI............................ 29

3.5.1 Avaliação da integridade de membrana e formação de autófagossomos usando marcação por sondas fluorescentes....................... 29

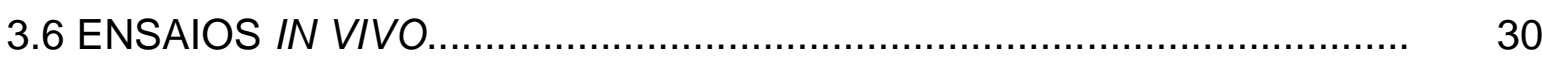

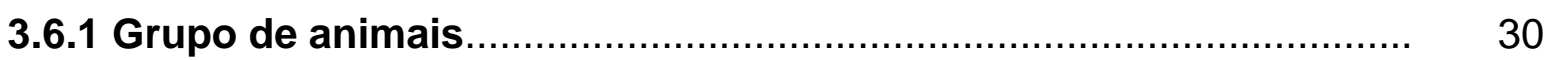

3.6.2 Análise qualitativa e quantitativa do oograma ............................... 30

3.6.3 Avaliação da peroxidação lipídica em amostras de fígado.............. 31

3.6.3.1 Determinação das substâncias reativas do ácido tiobarbitúrico (SRAT) presentes nas amostras de fígado....................................... 31

3.6.3.2 Dosagem do ácido tiobarbitúrico (TBA) nos homogeneizados............ 31

3.7 ANÁLISE ESTATÍSTICA................................................................. 32

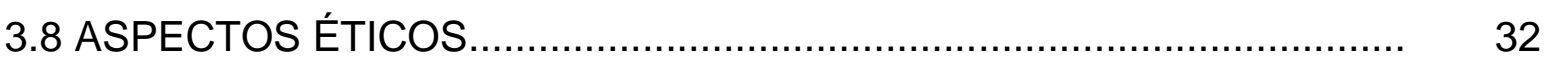

4 RESULTADOS E DISCUSSÃO 
4.1 ENSAIOS DE INIBIÇÃO DA ATIVIDADE ENZIMÁTICA DA APIRASE DA BATATA..

4.2 ENSAIOS PARA AVALIAÇÃO DA INTEGRIDADE DE MEMBRANA E FORMAÇÃO DE AUTOFAGOSSOMOS USANDO MARCAÇÃO POR SONDAS FLUORESCENTES.......................................................... $\quad 36$

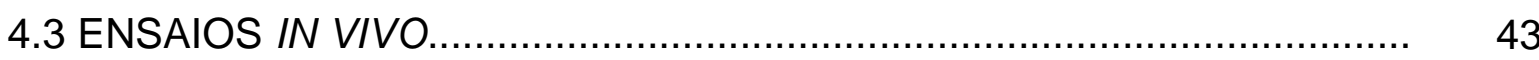

4.3.1 Recuperação de vermes............................................................. 43

4.3.2 Análise qualitativa e quantitativa do oograma ................................ 48

4.3.3 Avaliação da peroxidação lipídica nas amostras de fígado............. 51

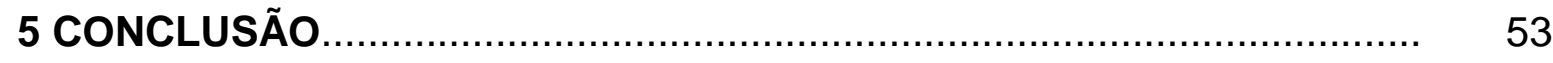
REFERÊNCIAS 


\section{INTRODUÇÃO}

\subsection{CONSIDERAÇÕES SOBRE DOENÇAS NEGLIGENCIADAS}

As doenças negligenciadas constituem um grupo especial de afecções que predominam em condições de pobreza, sendo tanto causa como consequência da violação de direitos humanos (HUNT et al., 2007). De acordo com a Organização Mundial da Saúde (OMS), são doenças negligenciadas: leishmaniose, oncocercose, doença de chagas, hanseníase, tuberculose, esquistossomose, tripanossomíase africana e dengue. Algumas dessas doenças são fatais para o ser humano, enquanto outras resultam em alta morbidade e deficiências graves. Ainda, estimativas da OMS apontam que cerca 1 bilhão de pessoas, ou seja, um sexto da população mundial, têm sua saúde impactada por doenças negligenciadas, apresentando deficiências graves e permanentes, e deformidades causadas por tais doenças (KINDHAUSER et al., 2003).

Além do sofrimento físico e psicológico, as doenças negligenciadas causam um enorme fardo econômico às comunidades afetadas devido à perda da produtividade e aos altos custos associados aos cuidados de longa duração, que por sua vez contribuem para a manutenção do ciclo perverso da pobreza e da falta de saúde nas populações mais pobres (HUNT et al., 2007).

Paradoxalmente, apesar de existir financiamento para pesquisas relacionadas às doenças negligenciadas, o conhecimento cientifico não se reverte em avanços terapêuticos, como o surgimento de novos fármacos, métodos diagnósticos ou vacinas. Para elucidar tal problemática, Pedrique e colaboradores (2013) verificaram que entre o período de 2000 a 2011, dos 850 novos produtos terapêuticos aprovados, apenas $37(4 \%)$ foram direcionados às doenças negligenciadas. Ainda, nesta mesma avaliação sistemática, foi identificado que dos 148.445 testes clínicos registrados, apenas 2016 (1\%) foram para doenças negligenciadas, apesar de tais afecções representarem $11 \%$ da carga global de doenças (DNDi, 2017).

Diante disso, pode-se relacionar o baixo interesse da indústria farmacêutica nesse grupo de doenças ao reduzido potencial de retorno lucrativo para essa indústria, uma vez que a maior população atingida é de baixa renda e presente, 
majoritariamente, nos países em desenvolvimento ou subdesenvolvidos, portanto, com baixa capacidade de compra (BRASIL, 2010).

Nesse cenário, a esquistossomose ganha destaque no rol das doenças negligenciadas por ser a terceira mais devastadora doença tropical no mundo, sendo a maior causa de morbimortalidade na África, América do Sul, Oriente Médio e Ásia. De acordo com a OMS, existem aproximadamente 800 milhões de pessoas vivendo em áreas endêmicas, sendo afetados em torno de 240 milhões de indivíduos nas regiões tropicais e subtropicais (ROSS et al., 2016; WHO, 2017).

No Brasil, as áreas endêmicas e focais abrangem 19 unidades federadas. A forma endêmica ocorre nos estados de Alagoas, Maranhão, Bahia, Pernambuco, Rio Grande do Norte, Paraíba, Sergipe, Espírito Santo e Minas Gerais, enquanto que nos estados do Pará, Piauí, Ceará, Rio de Janeiro, São Paulo, Santa Catarina, Paraná, Rio Grande do Sul, Goiás e no Distrito Federal, a transmissão é focal, não atingindo grandes áreas (BRASIL, 2014).

De fato, as maiores prevalências da esquistossomose são encontradas nas regiões Nordeste e Sudeste do País, havendo um destaque, atualmente, para uma distribuição mais intensa numa faixa de terras contínuas e contíguas ao longo de quase toda a costa litorânea da região Nordeste, a partir do Rio Grande do Norte em direção ao Sul, incluídas as zonas quentes e úmidas dos estados da Paraíba, Pernambuco, Alagoas, Sergipe e Bahia, onde se interioriza alcançando Minas Gerais, no Sudeste, seguindo o trajeto de importantes bacias hidrográficas (BRASIL, 2014).

Na região Sudeste, o estado de Minas Gerais segue a anos se destacando como uma área altamente endêmica. Segundo o Ministério da Saúde, no ano de 2015, 84,07\% do número de casos de esquistossomose ocorreram em Minas Gerais, e, de acordo com o Sistema de Informação sobre Mortalidade (SIM), das 147 mortes por esquistossomose registradas no Sudeste, 53,74\% dessas foram ocorridas em Minas Gerais (BRASIL, 2018).

A figura 1 ilustra a distribuição da esquistossomose segundo percentual de positividade em inquéritos coproscópicos. Destaque-se, entretanto, que o indicador de percentual de positividade não reflete necessariamente a prevalência, na medida em que não utiliza como denominador a totalidade da população sob risco ou uma parcela representativa desta. Desse modo, esse percentual pode ser considerado apenas como uma aproximação da prevalência, especialmente em populações 
menores, como as que estão representadas na maioria das localidades trabalhadas pelo Programa de Vigilância e Controle da Esquistossomose.

Figura 1 - Distribuição da esquistossomose segundo percentual de positividade em inquéritos coproscópicos - Brasil, 2012.

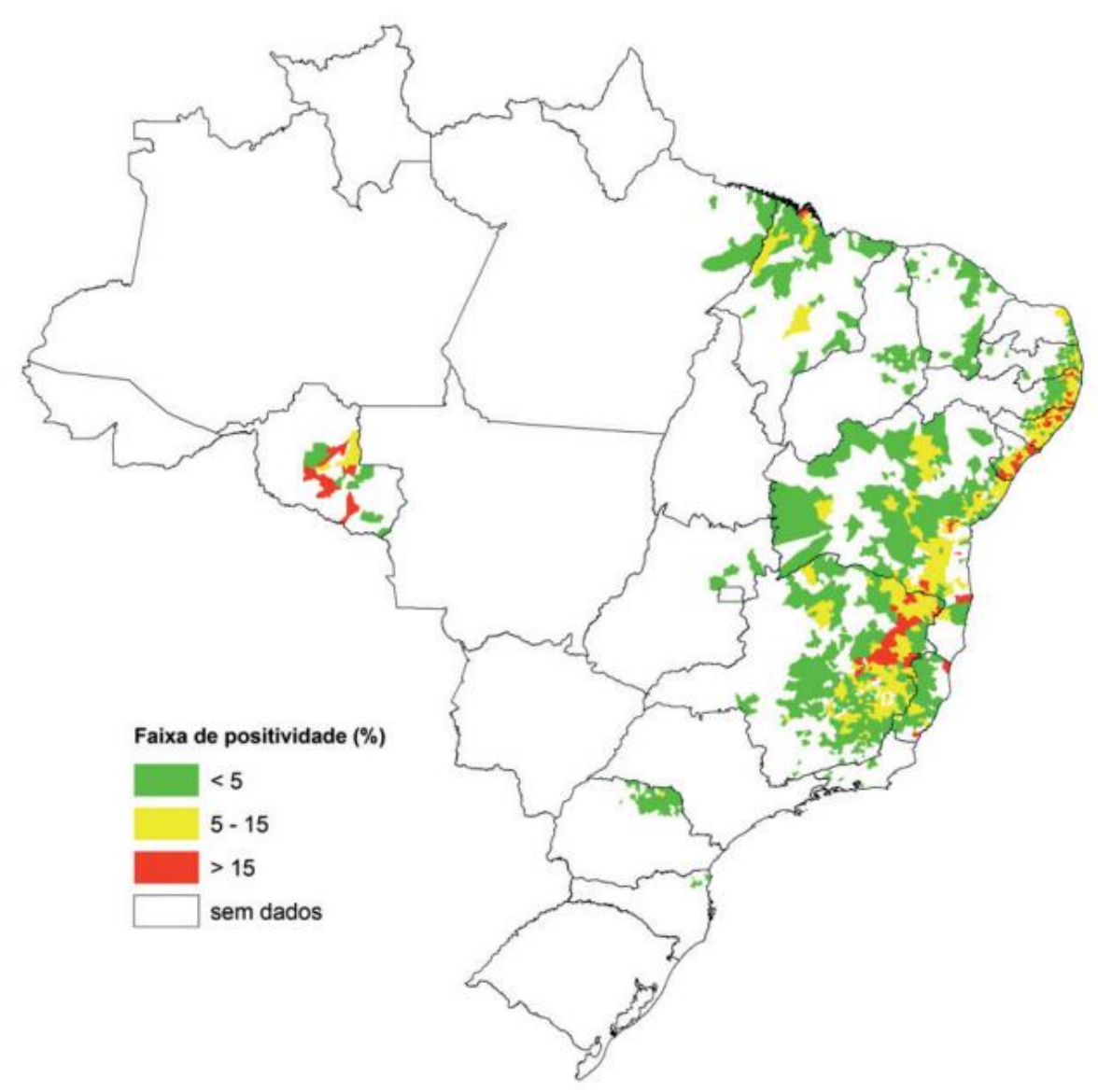

Fonte: Sistema de Informação do Programa de Vigilância e Controle da Esquistossomose - SISPCE/SVS/MS.

\subsection{ESQUISTOSSOMOSE MANSÔNICA: CICLO BIOLÓGICO E TERAPIA FARMACOLÓGICA}

A esquistossomose mansônica é uma doença infecto-parasitária, cujo agente etiológico causador da doença, no homem, é o trematódeo Schistosoma mansoni. A infecção por esse agente está relacionada à continuação do seu ciclo biológico complexo, que se compõe de três etapas: uma etapa de reprodução sexuada, onde os vermes adultos, dioicos, produzem ovos no hospedeiro intermediário (homem); 
uma outra etapa de reprodução assexuada (esporocistos) nos hospedeiros intermediários (caramujos do gênero Biomphalaria); e, por fim, as fases de vida livre, ocorrendo as de miracídios e cercárias (forma infectante que penetram na pele). No homem, as cercárias transformam-se rapidamente em esquistossômulos, com características morfológicas e bioquímicas diferentes. Os esquistossômulos perfazem ciclos sistêmicos, carregados passivamente pela corrente sanguínea, passando por órgãos como coração e pulmões, até que ficam retidos nos sinusóides hepáticos, onde se desenvolvem e amadurecem sexualmente. Os vermes adultos acasalam-se, e as fêmeas passam a liberar ovos imaturos no sistema porta-hepático intestinal. Os ovos desenvolvem-se nos tecidos deste hospedeiro intermediário e então são liberados através das fezes, contaminando ambientes aquáticos, o que dá continuidade ao ciclo biológico (CARVALHO; COELHO; LENZI, 2008). A figura 2 ilustra resumidamente o ciclo biológico do $S$. mansoni.

Figura 2 - Ciclo biológico do Schistosoma mansoni.

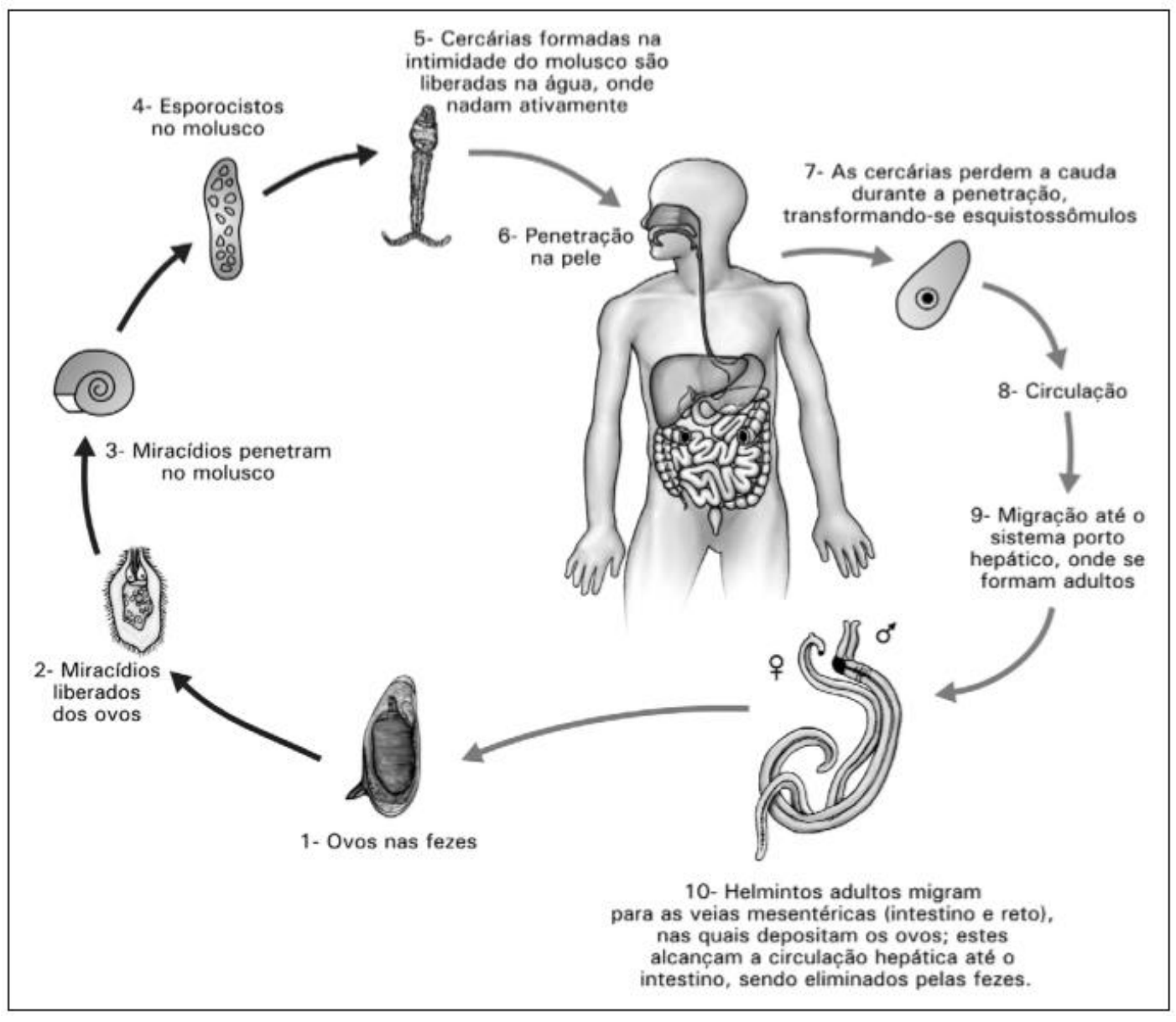

Fonte: SOUZA et al., 2011 
No homem, a esquistossomose se apresenta sob uma forma aguda e duas formas crônicas: uma crônica habitual ou leve, também chamada de forma hepatointestinal, que atinge a maioria absoluta dos indivíduos infectados e geralmente é assintomática; a outra forma crônica (hepatoesplênica), considerada a forma grave ou avançada da esquistossomose, que é mais rara e manifesta-se com hepatoesplenomegalia e outros sinais de hipertensão portal, devido ao aumento de lesões fibróticas, destrutivas e obstrutivas do sistema da veia porta intra-hepático, além de uma expansão fibrosa sistematizada dos espaços porta (CARVALHO; COELHO; LENZI, 2008).

A terapia farmacológica da esquistossomose em fase crônica, no Brasil, está baseada na utilização de duas drogas esquistossomicidas: o praziquantel (PZQ), medicamento de amplo espectro (figura 3a); e a oxamniquina (figura $3 b$ ), que se mostra eficaz no tratamento da doença contra vermes de $S$. mansoni, porém ineficaz nas infecções por $S$. hematobium ou $S$. japonicum. (DOENHOFF; CIOLI; UTZINGER, 2008; CARVALHO; COELHO; LENZI, 2008).

Usado para tratamento da esquistossomose em larga escala, o praziquantel, um derivado pirazino-isoquinoleínico do grupo dos tioxantônicos, é comercialmente utilizado como uma mistura racêmica, insolúvel em água, mas solúvel em alguns solventes orgânicos. No Brasil, ele é apresentado em comprimidos de $600 \mathrm{mg} e$ administrado por via oral, em dose única de $50 \mathrm{mg} / \mathrm{kg}$ de peso para adultos e de 60 $\mathrm{mg} / \mathrm{kg}$ de peso para crianças (BRASIL, 2017).

Embora não se saiba ao certo o mecanismo de ação do praziquantel, sabese que o influxo do íon $\mathrm{Ca}^{2+}$ representa um importante papel na ação da droga, o que resulta na morte dos vermes por meio de lesões do tegumento, contrações musculares e alterações metabólicas (DOENHOFF; CIOLI; UTZINGER, 2008).

Ainda em relação ao praziquantel, é observado que esse fármaco atinge taxas de cura de $80 \%$ a $90 \%$ dos casos de pacientes infectados, mas curas de $100 \%$ são raras. Adicionalmente, algumas limitações no tratamento com essa droga são observadas, pois ela não age sobre os esquistossômulos (vermes jovens que estão em migração), ou seja, não interfere nos estágios iniciais da doença (DOENHOFF; CIOLI; UTZINGER, 2008; CARVALHO; COELHO; LENZI, 2008).

Por sua vez, a oxamniquina, molécula pertencente à classe das tetraidroquinolinas, apresenta índice de cura semelhante ao praziquantel, estando disponível, no Brasil, sob duas apresentações comerciais: cápsulas com 250 mg de 
sal ativo e solução contendo $50 \mathrm{mg} / \mathrm{mL}$, para uso pediátrico. De acordo com o atual protocolo clínico, as doses recomendadas são de $20 \mathrm{mg} / \mathrm{kg}$ para crianças e de 15 $\mathrm{mg} / \mathrm{kg}$ para adultos (BRASIL, 2017).

Assim como o praziquantel, o mecanismo de ação da oxamniquina não é totalmente esclarecido, mas parece estar relacionado com a capacidade de inibição irreversível da síntese dos ácidos nucleicos nos vermes (CIOLI; PICA-MATTOCCIA; ARCHER, 1993).

Apesar desses dois medicamentos fazerem parte do Componente Estratégico da Assistência Farmacêutica na RENAME (Relação Nacional de Medicamentos), sendo distribuídos gratuitamente pelo sistema público de saúde, na rotina do Programa de Controle da Esquistossomose (PCE), o praziquantel é o único medicamento utilizado (BRASIL, 2017).

Figura 3 - Estrutura química do praziquantel (a) e oxamniquina (b).

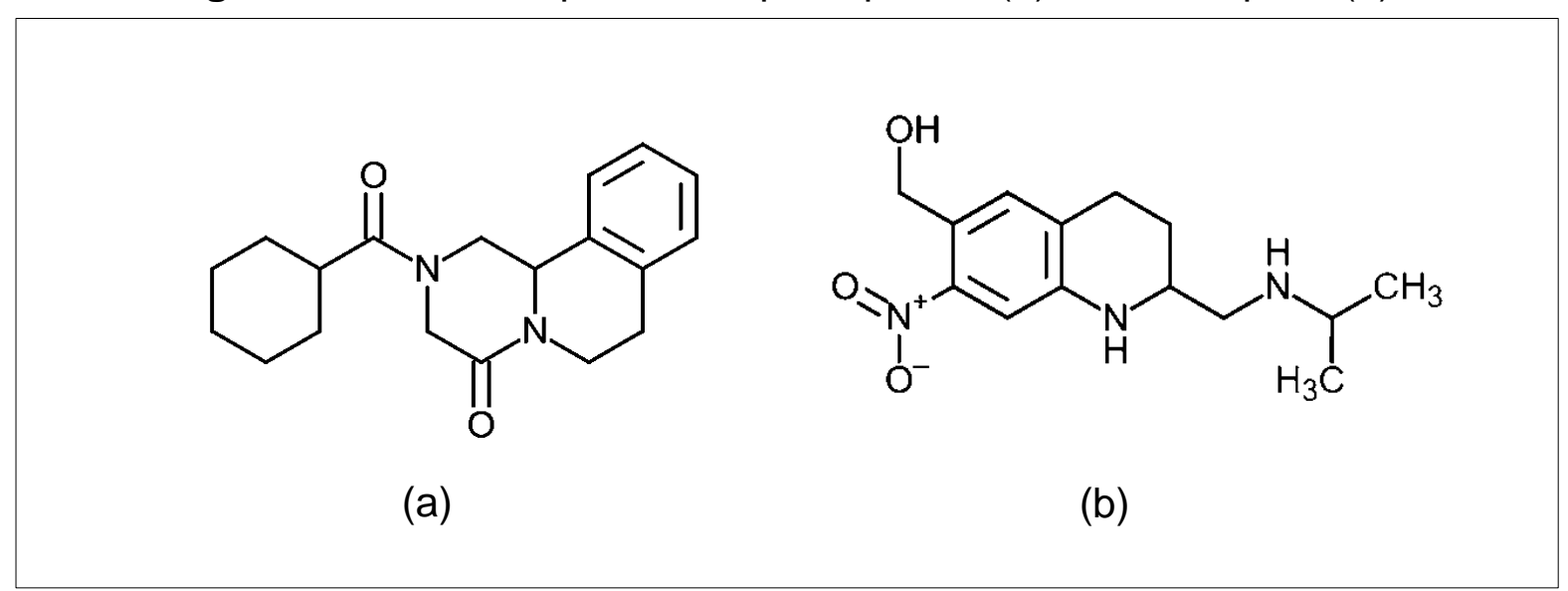

Fonte: elaboração própria.

Adicionalmente, embora sejam eficazes contra os vermes de S. mansoni, a literatura relata a presença do fator de resistência de algumas cepas às drogas atualmente disponíveis (CIOLI; PICA-MATTOCCIA; ARCHER, 1993). Nesse sentido, a busca por novas entidades farmacológicas que possam atuar no combate à esquistossomose continua sendo um ponto estratégico relevante, aliado ao controle sanitário e educação em saúde das populações vulneráveis (REMME at al., 2002)

Por fim, a OMS inclui a esquistossomose na sua lista das dez doenças parasitárias prioritárias, destacando-se a necessidade da busca de novos fármacos para essa doença (WHO, 2017). 


\subsection{CONSIDERAÇÕES SOBRE FLAVONOIDES E AURONAS}

Os flavonoides correspondem a um dos grupos de compostos fenólicos mais importantes e diversificados entre os produtos de origem natural, amplamente difundidos no reino vegetal, sendo quase ausente em algas. Ainda, há relatos na literatura em relação à presença de alguns representantes em briófitas, existindo somente um relato de ocorrência em fungos. Em relação às pteridófitas, é relatado a ocorrência de alguns flavonoides, embora ocorram com uma reduzida variabilidade estrutural. Todavia, as angiospermas reúnem uma extensa diversidade estrutural destes compostos (SIMÕES et al., 2010).

Etimologicamente falando, o nome flavonoide deriva do latim "flavus" = amarelo e "oide" = forma, fazendo referência aos pigmentos amarelados encontrados nas flores. Entretanto, eles também são responsáveis pelos tons alaranjados, azulados e vermelhos de muitos vegetais. Tais substâncias são responsáveis por funções biológicas que garantem o equilíbrio ecológico, como proteção contra a radiação ultravioleta, regulação do crescimento e desenvolvimento normal das plantas, defesa contra fungos, bactérias e vírus; além de quelarem metais tóxicos e reduzirem os agentes oxidativos lesivos à própria planta (MUSCHIETTI; MARTINO, 2007; SIMÕES et al., 2010).

Além disso, os flavonoides estão envolvidos no processo de transferência de energia, morfogênese, determinação do sexo das plantas, respiração e fotossíntese da maioria das plantas (MUSCHIETTI; MARTINO, 2007).

A maioria dos flavonoides apresenta um núcleo fundamental contendo 15 átomos de carbono, correspondendo à uma estrutura básica de duas fenilas ligadas por uma cadeia de três carbonos entre elas, como mostra a figura 4 (SIMÕES et al., 2010). Adicionalmente, tal núcleo básico pode sofrer algumas variações, seja por meio de oxidações ou substituições nos anéis, hidrogenação, hidroxilação, metilação, sulfatação e glicosilação, originando diversos tipos de flavonoides (HUBINGER, 2009) 
Figura 4 - Núcleo fundamental dos flavonoides.

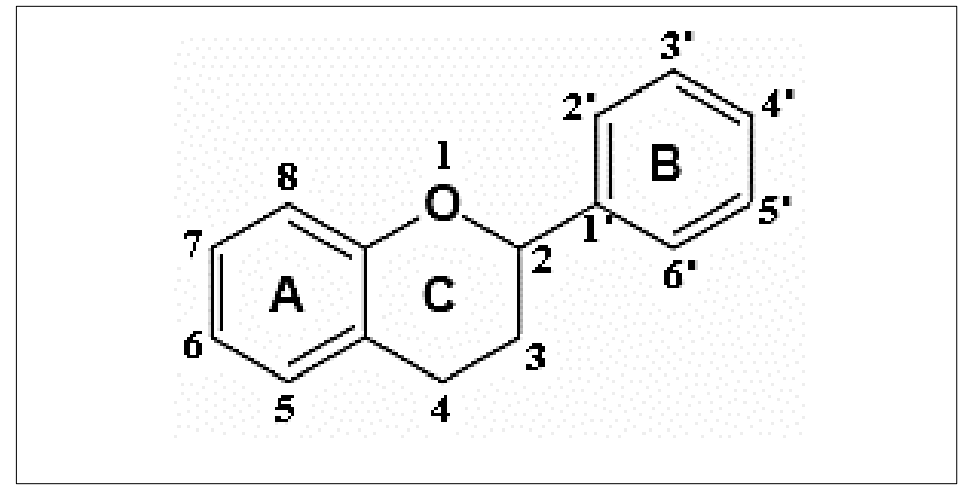

Fonte: HUBINGER, 2009.

Dentre os flavonoides de ocorrência natural, as auronas correspondem a um grupo de metabólitos secundários encontrado em plantas - como Antirrhinum majus (boca de lobo), Cosmos sulphureus (cosmos) e Dahlia pinnata (dália) -, contribuindo para a coloração amarelada das pétalas das flores e para a proteção contra radiação solar e predadores; ainda, as auronas podem ser encontradas em alguns organismos marinhos (HUANG et al., 2008; RAHMAN et al., 2001; BOUMENDJEL, 2003).

Além da ocorrência natural, as auronas podem ser obtidas por meio de reações de ciclização oxidativa de chalconas e 1-(2-hidroxifenil)-3-fenilpropinóis; a partir da ciclização de chalconas em meio de DMSO e acetato de mercúrio (BHASKER; REDDY, 2011); a partir da reação de condensação entre benzofuronas e derivados de benzaldeídos, em meio ácido (CHENG et al., 2010) ou meio básico (SOUARD et al., 2010), dentre outras formas de obtenção.

Ainda, de acordo com a literatura, por apresentarem em seu esqueleto básico (figura 5) anéis aromáticos, as auronas permitem, no processo de síntese, a inserção de diferentes substituintes nessas estruturas, gerando-se compostos ricos em atividade biológica (SILVEIRA, 2013). 
Figura 5 - Estrutura básica das auronas.

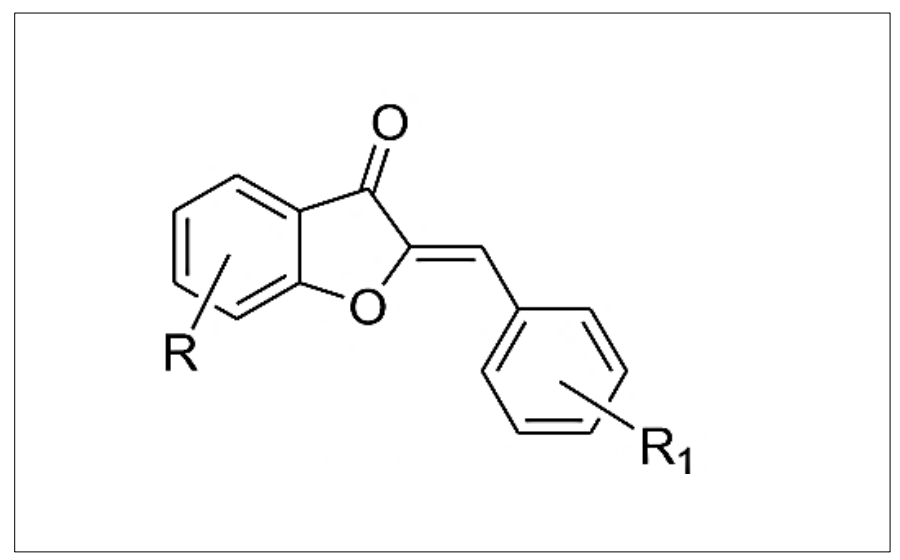

Fonte: SILVEIRA, 2013.

Em relação ao potencial biológico das auronas, vários estudos revelaram propriedades promissoras, tais como: ação anti-inflamatória, por mecanismo de inibição da 5-lipoxigenase (DETESI et al., 2009), antifúngica (BANDGAR et al., 2010) e antibacteriana (VENKATESWARLU et al., 2007). Além disso, ação antiparasitária contra Plasmodium falciparum (KAYSER, KIDERLEN, BRUN, 2001; SOUARD et al., 2010) e leishmanicida (ROUSSAKI et al., 2012) são descritas na literatura, o que reforça a importância da investigação biológica dessa classe de compostos em outros modelos experimentais, como por exemplo os de outras doenças infecto parasitárias.

Adicionalmente, estudos realizados pelo Núcleo de Identificação e Pesquisa de Princípios Ativos Naturais - NIPPAN, da Faculdade de Farmácia da Universidade Federal de Juiz de Fora, grupo de pesquisa coordenado pelo professor Doutor Ademar Alves da Silva Filho, identificaram que em ensaios in vitro contra os vermes adultos de S. mansoni as auronas sintéticas codificadas como LS23, LS26 e LS29 (figura 6) causaram alterações no tegumento, redução da atividade motora e morte de $100 \%$ dos vermes, nas concentrações de 100 e $50 \mu \mathrm{M}$, em comparação aos grupos controle (DMSO 0,5\%) e controle $\mathrm{PZQ}$, assim como ao grupo que não recebeu tratamento.

Desse modo, tornou-se motivador um estudo mais aprofundado da ação dessas drogas no modelo experimental de esquistossomose, assim como foi relevante a investigação de um possível mecanismo de ação sobre os vermes adultos. 
Figura 6 - Estrutura química das auronas LS23, LS26 e LS29.

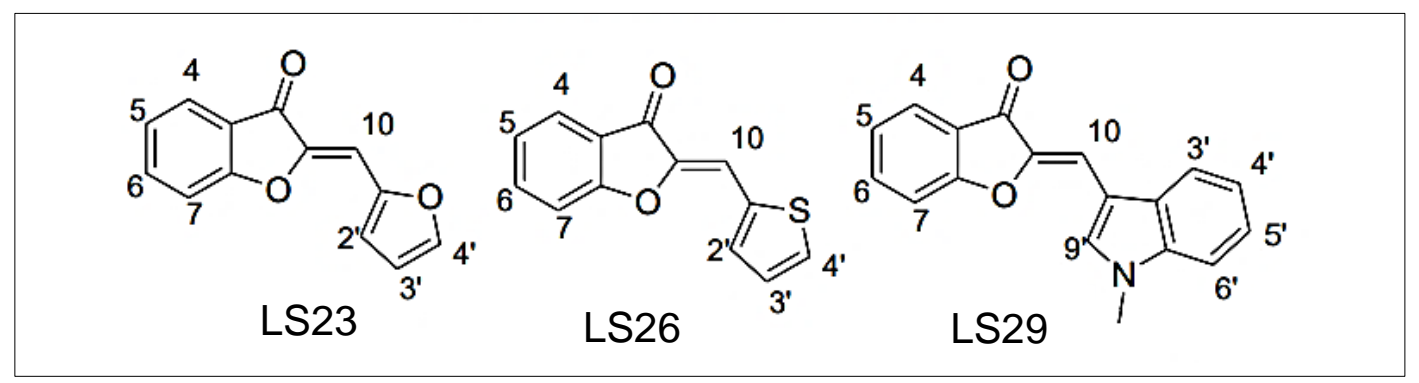

Fonte: SILVEIRA, 2013 (Adaptado).

\subsection{CONSIDERAÇÕES SOBRE NTPDASES E SUA RELEVÂNCIA NA ESQUISTOSSOMOSE COMO ALVO TERAPÊUTICO}

Amplamente distribuídas nos organismos eucariotos, as NTPDases (EC 3.6.1.5) correspondem a uma família de proteínas que têm como característica comum a capacidade de hidrolisar nucleotídeos di- e trifosfatados (ADP e ATP) na presença de cátions bivalentes $\left(\mathrm{Ca}^{+2} \mathrm{e} \mathrm{Mg}^{+2}\right)$ em concentrações milimolares, tendo como produto final da hidrólise nucleosídeos monofosfatados (ZIMMERMANN, ZEBISCH, STRATER, 2012).

Ainda, tais enzimas apresentam uma outra característica comum: a presença de cinco regiões conservadas de apirase (ACRs), onde ocorrem sequencias conservadas de resíduos de aminoácidos essenciais para a sua função enzimática (HANDA, GUIDOTTI, 1996; VASCONCELOS et al., 1996).

A literatura relata a ocorrência de membros dessa família de enzimas em diversos parasitos que afetam a saúde humana, tais como: S. mansoni, Toxoplasma gongii, Entamoeba hystolytica, Trichomonas vaginalis, Leishmania amazonenses, e Trypanosoma cruzi (ASAl et al., 1992; VASCONCELOS et al., 1993; 1996; BARROS et al., 2000; COIMBRA et al., 2002; FIETTO et al., 2004; FARIA-PINTO et al., 2004).

Além disso, em muitos desses estudos é destacada a presença da atividade de NTPDases nos processos de aquisição de nutrientes, de assimilação de purinas e nos fatores de virulência de alguns parasitos. Em S. mansoni, por exemplo, é sugerido que a atividade das NTPDases presentes na superfície do parasito ajude a limitar a resposta inflamatória e o processo de trombose em torno do verme, uma vez que essas enzimas reduzem a concentração extracelular do ATP que é liberado pelas células do hospedeiro em resposta ao dano tecidual (BHARDWAJ, SKELLY, 2009). 
Ainda em relação à presença de NTPDases em $S$. mansoni, alguns estudos caracterizaram duas isoformas dessa enzima (SmNTPDase1 e SmNTPDase2), com massa molecular aproximada de $63 \mathrm{kDa}$, diferindo na razão de atividade ATPásica/ADPásica, ponto isoelétrico e solubilidade em detergentes (VASCONCELOS et al., 1993; 1996).

Em adição a essas diferenças, o padrão de localização dessas enzimas também difere, de modo que a isoforma SmNTPDase1 apresenta-se localizada na superfície do parasito, sugestivamente ancorada na membrana pelos seus domínios transmembranares $\mathrm{N}$ e C-terminais previstos. Já a isoforma SmNTPDase2 apresenta em sua região amino terminal um único sítio de ligação à membrana que, quando clivado, libera a proteína na forma solúvel (VASCONCELOS et al., 1993; LEVANO-GARCIA et al., 2007).

Além da presença nos vermes adultos, as isoformas de NTPDases foram identificadas em todos os estágios do ciclo de vida deste helminto, corroborando a ideia de que a atividade dessas enzimas nos diferentes estágios de vida do parasito associa-se com a manutenção dos seus processos fisiológicos (LEVANO-GARCIA et al., 2007).

Por sua vez, também pertencente à família das NTPDases, a apirase da batata (Solanum tuberosum) há alguns anos vem sendo estudada por pesquisadores de diversas áreas devido ao seu potencial como ferramenta biotecnológica aplicada a diversos modelos experimentais, como por exemplo em estudos imunológicos da esquistossomose e de busca por novas drogas esquistossomicidas (VASCONCELOS et al., 1996; FARIA-PINTO et al., 2004; PENIDO et al., 2007).

Faria-Pinto e colaboradores (2004) observaram que anticorpos IgG do soro de camundongos infectados com $S$. mansoni apresentavam uma alta reatividade com a apirase da batata, revelando a ocorrência de domínios antigênicos compartilhados entre a proteína vegetal e as isoformas de NTPDases de S. mansoni. Mais tarde, estudos preditivos das estruturas tridimensionais da apirase da batata e da SmATPDase2 de $S$. mansoni revelou um elevado grau de semelhança tanto entre a estrutura primária quanto entre a estrutura tridimensional dessas proteínas, além de serem identificados os domínios compartilhados e com alto potencial para a ligação de anticorpos (FARIA-PINTO, 2008). 
Em estudos que buscam novas drogas esquistossomicidas, a relação entre a apirase da batata e as NTPDases de $S$. mansoni também é explorada. Para exemplificar, um estudo realizado por Penido e colaboradores (2007) revelou que ácidos alquilaminoalcanotiossulfúricos foram capazes de causar a inibição da atividade enzimática das isoformas de NTPDases presentes no tegumento dos vermes de $S$. mansoni e da apirase da batata usada nesse ensaio.

Com base nisso, e sabendo do alto potencial da apirase da batata como ferramenta em estudos de monitoramento da atividade ATPásica/ADPásica em ensaios de inibição enzimática, torna-se interessante a realização de ensaios de inibição enzimática utilizando a apirase da batata, facilmente obtida por métodos convencionais de purificação, como ferramenta de triagem na busca de inibidores de NTPDases (VASCONCELOS et al., 2009).

\subsection{ESQUISTOSSOMOSE E PEROXIDAÇÃO LIPÍDICA}

Em indivíduos infectados com S. mansoni, a lesão fundamental causada pela inflamação granulomatosa, característica da doença, associa-se com o aumento do dano oxidativo através da geração de radicais livres e espécies reativas de oxigênio (ERO) nos tecidos do hospedeiro, principalmente no fígado e intestino, em resposta à presença dos ovos altamente imunogênicos (CUNHA, 2008; FREITAS et al., 2016).

Um dos efeitos do aumento de espécies reativas de oxigênio é o ataque a estruturas celulares tais como proteínas, carboidratos, lipídeos e ácidos nucleicos (NELSON; COX, 2011). Em relação aos lipídios de membranas, por meio do processo chamado de peroxidacao lipídica, ácidos graxos poli-insaturados, como o ácido araquidônico, podem gerar compostos intermediários de alta reatividade com o ácido tiobarbitúrico (TBA) ditas substâncias reativas do ácido tiobarbitúrico (SRAT) como o malondialdeído (MDA), dialdeído volátil e de baixo peso molecular $\left(\mathrm{C}_{3} \mathrm{H}_{4} \mathrm{O}_{2}\right.$, P.M. = 72,07), gerado a partir da oxidação do ácido araquidônico (NAVAB et al., 1996).

$\mathrm{Na}$ esquistossomose, existe uma associação entre a infecção parasitária e níveis aumentados de SRAT e ERO circulantes (EBOUMBOU et al., 2005). Desse modo, um dos meios de se identificar experimentalmente o nível de peroxidação lipídica em amostras biológicas seria por meio do método colorimétrico em que se 
usa o TBA, onde é identificado o complexo formado por meio da reação de condensação entre esse composto e as SRAT, principalmente o MDA. Esse complexo MDA:TBA (1:2), de fórmula molecular $\mathrm{C}_{11} \mathrm{H}_{8} \mathrm{~N}_{4} \mathrm{~S}_{2} \mathrm{O}_{4} \cdot \mathrm{H}_{2} \mathrm{O}$ (P.M.=342,35), apresenta fluorescência entre $515 \mathrm{~nm}$ e $553 \mathrm{~nm}$ e absorção máxima em $532 \mathrm{~nm}$, sendo facilmente detectado em espectrofotômetro (LIMA; ABDALLA, 2001).

Visto isso, e sabendo da capacidade intrínseca de flavonoides como bons agentes antioxidantes (MUSCHIETTI; MARTINO, 2007), a exemplo das auronas, tornou-se interessante agregar ao nosso estudo a investigação da contribuição desses compostos frente à patologias que aumentam o estresse oxidativo nos tecidos e o nível de peroxidacão lipídica, como ocorre na esquistossomose a nível do fígado, um dos órgãos mais comprometidos nesta afecção. 


\section{OBJETIVOS}

\subsection{OBJETIVO GERAL}

Avaliar o potencial de auronas sintéticas em modelos in vivo e in vitro de esquistossomose murina.

\subsection{OBJETIVOS ESPECÍFICOS}

- Verificar o efeito das auronas nos ensaios de inibição da atividade enzimática da apirase de batata;

- Observar o possível efeito dessas moléculas sobre a integridade de membrana (permeabilidade) e geração de autofagossomos nos vermes adultos por meio da marcação por sondas fluorescentes em ensaios in vitro;

- Verificar o efeito destas auronas sintéticas, administradas por via oral, sobre o tratamento da esquistossomose em modelo murino, avaliando-se a redução da carga parasitária e oograma;

- Avaliar o efeito das auronas como agentes antioxidantes in vivo no processo de peroxidação lipídica. 


\section{METODOLOGIA}

\subsection{DELINEAMENTO EXPERIMENTAL E LOCAL DE PESQUISA}

Foi realizado um estudo laboratorial experimental, de caráter qualiquantitativo, no Laboratório de Esquistossomose do Centro de Pesquisas René Rachou, Fiocruz/MG, em parceria com no Laboratório de Estrutura e Função de Proteínas, do Departamento de Bioquímica da Universidade Federal de Juiz de Fora.

\subsection{OBTENÇÃO DAS AURONAS}

As moléculas foram cedidas pelo Núcleo de Identificação e Pesquisa de Princípios Ativos Naturais - NIPPAN, da Faculdade de Farmácia da Universidade Federal de Juiz de Fora, coordenado pelo professor Doutor Ademar Alves da Silva Filho.

As três auronas usadas neste estudo foram obtidas por meio de reações de ciclização oxidativa a partir de chalconas, usando acetato de mercúrio (II) em piridina, sob aquecimento, de acordo com técnica descrita por Silveira (2013). A síntese dessas moléculas ocorreu no próprio NIPPAN, no segundo semestre de 2017.

\subsection{INFECÇÃO E CICLO}

Os camundongos albinos da linhagem Swiss obtidos e mantidos nas dependências do Biotério do Centro de Pesquisas René Rachou, foram submetidos à infecção bissexual, por via subcutânea, com aproximadamente 50 cercárias/animal. As condições de acesso à ração e à água foram mantidas ad libitum.

Ao final de 55-60 dias pós-infecção, os animais foram eutanaziados sob anestesia profunda com Ketamina e Xilazina nas doses de $90 \mathrm{mg} / \mathrm{kg}$ e $10 \mathrm{mg} / \mathrm{kg}$ de peso corporal, respectivamente. Após a eutanásia, os animais foam perfundidos para a recuperação de vermes adultos do sistema porta-hepático, método adaptado da técnica descrita por Pellegrino e Siqueira (1956). 


\subsection{ENSAIOS DE INIBIÇÃO DA ATIVIDADE ENZIMÁTICA DA APIRASE DA BATATA}

O produto da atividade enzimática foi avaliado de acordo com o método modificado de Taussky \& Shorr (1953). Nesses ensaios, 0,5 $\mathrm{ng}$ de apirase de batata purificada foi adicionada ao meio de reação contendo volumes variáveis $(\mu \mathrm{L})$ de água deionizada, $50 \mu \mathrm{L}$ de tampão succinato $5 x$ concentrado e volumes variáveis $(\mu \mathrm{L})$ da solução da droga de interesse, totalizando um volume de $250 \mu \mathrm{L}$. Os tubos foram incubados durante 10 minutos em banho-maria a $37^{\circ} \mathrm{C}$ para estabilização do sistema e a reação foi disparada com a adição de $7,5 \mu \mathrm{L}$ de ATP $0,1 \mathrm{M}$. Após 10 minutos, a reação foi interrompida pela adição de $250 \mu \mathrm{L}$ de $\mathrm{HCl} 0,1 \mathrm{~N}$. A quantidade de fosfato inorgânico ( $\mathrm{Pi}$ ) liberado foi determinada pela adição de $500 \mu \mathrm{L}$ de reagente de cor ( $\mathrm{FeSO}_{4}, \mathrm{H}_{2} \mathrm{SO}_{4}$, molibdato de amônio e água deionizada). Após 30 minutos da adição do reagente de cor, a medida da densidade óptica foi feita em espectrofotômetro em $660 \mathrm{~nm}$.

As concentrações finais de droga testadas após adição ao meio de reação foram: $1 \mathrm{mM}, 0,1 \mathrm{mM}, 0,01 \mathrm{mM}, 0,001 \mathrm{mM}$ e $0,0001 \mathrm{mM}$. Em cada ensaio, para cada concentração, foram realizadas duplicatas do grupo branco, onde a amostra proteica foi adicionada após o término da reação, e triplicatas do grupo teste, onde a amostra proteica já fora adicionada ao meio reacional antes da reação ser disparada.

Para cada experimento, foram realizadas uma medida de atividade enzimática basal (controle) ou atividade enzimática do grupo controle do veículo usado para solubilizar a droga ( $50 \%$ v/v glicerol PA e 50\% etanol (5\%) preparado em água), em cada concentração. A partir desses valores, a atividade residual encontrada para cada droga foi subtraída da atividade enzimática basal, obtendo-se o percentual de inibição da atividade enzimática de cada teste. As fórmulas abaixo ilustram como foram calculadas a atividade e a porcentagem de inibição, respectivamente:

$$
\begin{aligned}
& \text { Atividade }_{\left(\text {nmolPi.mg }^{-1} \cdot \text { min }^{-1}\right)}=\frac{\text { atividade }_{\text {teste }}-\text { média atividade }_{\text {branco }}}{\text { conc.proteína } / \text { média }_{\text {curva }} / \text { tempo }_{\text {incubação }}}
\end{aligned}
$$

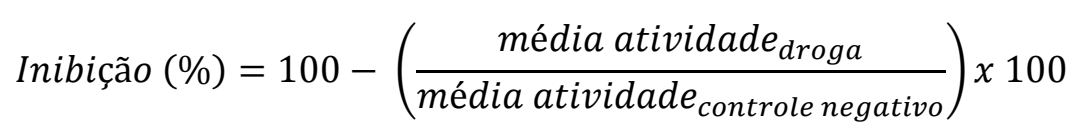




\subsection{AVALIAÇÃO IN VITRO DO EFEITO DAS AURONAS SOBRE OS VERMES ADULTOS DE SCHISTOSOMA MANSONI.}

\subsubsection{Avaliação da integridade de membrana e formação de autofagossomos usando marcação por sondas fluorescentes}

Para avaliar o efeito das drogas sobre a integridade da membrana dos vermes adultos de $S$. mansoni, assim como a formação de autofagossomos, foi utilizada a técnica de marcação por sonda fluorescente em conjunto com a microscopia de fluorescência. Para tanto, os grupos experimentais desse ensaio foram tratados com as drogas em concentrações, tendo por base o experimento realizado previamente pelo grupo do professor Ademar Filho, cujos resultados ainda não foram publicados. Assim, os vermes adultos foram expostos às drogas nas contrações $25 \mu \mathrm{M}$ ou $10 \mu \mathrm{M}$, existindo também a presença de grupos controles do veículo utilizado para solubilizar as auronas na maior concentração e um grupo controle do experimento, onde os vermes não foram expostos à droga ou veículo. Em cada poço foram colocados aproximadamente quatro vermes adultos, que permaneceram em cultura com ou sem contato com as drogas LS23, LS26 e LS29 por um período de $24 \mathrm{~h}$, em meio RPMI 1640 em estufa a $37^{\circ} \mathrm{C}$, com atmosfera de $5 \%$ de $\mathrm{CO}_{2}$.

$\mathrm{Na}$ avaliação da integridade da membrana -e consequente permeabilidade-, foram utilizados dextrans de diferentes pesos moleculares (10kDa, 20kDa e $40 \mathrm{kDa}$ ), acoplados ao fluoróforo FITC (isotiocianato de fluoresceína) denominados FITCDextrans, que são substâncias (sondas) comercialmente disponíveis as quais a membrana celular é impermeável. À medida em que é aumentada a formação de poros, essas sondas são cada vez mais captadas do meio (JEREMIAS, 2015). Todas essas sondas são solúveis em água e foram dissolvidas em meio de cultura RPMI 1640, para a concentração final de $1 \mathrm{mg} / \mathrm{mL}$. A partir das soluções estoque assim preparadas, foram devidamente diluídas no meio de cultura contendo os vermes, obtendo-se concentrações finais de $20 \mathrm{ng} / \mathrm{mL}$ em cada poço.

$\mathrm{Na}$ avaliação da formação de autofagossomos, foi utilizada a sonda monodansylcadaverin, que se liga especificamente aos autofagossomos, emitindo fluorescência verde quando observadas no microscópio de fluorescência (ALADHAMl et al., 2005). Para tanto, uma solução estoque foi preparada dissolvendo- 
se a sonda em meio de cultura RPMI 1640, obtendo-se uma concentração final de 1 $\mathrm{mg} / \mathrm{mL}$. A partir dessa solução, alíquotas foram adicionadas aos poços contendo os vermes, ajustando-se a concentração para $20 \mathrm{ng} / \mathrm{mL}$ em cada poço.

Após 30 minutos de incubação na presença das sondas dissolvidas em meio RPMI 1640 em estufa a $37^{\circ} \mathrm{C}$, com atmosfera de $5 \%$ de $\mathrm{CO}_{2}$, os vermes dos grupos experimentais anteriormente mencionados foram lavados 3 vezes pela substituição do meio de cultura sobrenadante. Por fim, os vermes foram avaliados em microscópio de fluorescência, e posteriormente, fotografados.

\subsection{ENSAIOS IN VIVO}

\subsubsection{Grupo de animais}

Camundongos fêmeas da linhagem Swiss, com peso de aproximadamente 20 $\mathrm{g}$, foram infectados com aproximadamente 50 cercárias/animal. Os animais foram divididos em 10 grupos experimentais $(n=15)$, incluindo um grupo controle composto por animais infectados e não tratados e um grupo controle tratado com praziquantel.

Para o tratamento com as auronas LS26 e LS29, emulsionadas em solução de DMSO a $0,5 \%$ preparada em solução tampão de salina fosfato (PBS - pH 7,4), foram utilizados 150 animais nos ensaios, sendo divididos em: grupo controle 1 (15 animais) que não recebeu intervenções durante o período experimental; grupo controle praziquantel (15 animais) que recebeu dose única $(200 \mathrm{mg} / \mathrm{kg}$ ) por via oral (gavagem) 50 dias após infecção; grupos tratados com a droga, em dose única, nas doses de $50 \mathrm{mg} / \mathrm{kg}$ (15 animais) e $100 \mathrm{mg} / \mathrm{kg}$ (15 animais), 50 dias após a infecção; grupos tratados com a droga, em duas doses, sendo estas administradas 40 e 50 dias após a infecção, também nas doses de $50 \mathrm{mg} / \mathrm{kg}$ (15 animais) e $100 \mathrm{mg} / \mathrm{kg}$ (15 animais).

A avaliação da ação esquistossomicida sobre os animais infectados foi realizada após 55-60 dias de infecção, por meio da eutanásia dos animais por deslocamento cervical. Os vermes, separados em machos, fêmeas ou casais, foram recuperados da perfusão dos camundongos tratados e contados/agrupados conforme a localização dos mesmos (se nas veias mesentéricas ou hepáticas). Os resultados foram comparados aos obtidos nos grupos-controles. 


\subsubsection{Análise qualitativa e quantitativa do oograma}

Para avaliar os efeitos sobre a evolução dos ovos, foram realizados oogramas com uma porção de cerca de $1 \mathrm{~cm}$ da junção ileocecal dos animais submetidos aos tratamentos e do grupo controle não tratado. O fragmento de intestino foi ligeiramente seco em papel absorvente e mantido pressionado entre uma lâmina de vidro e uma lamínula de plástico. Os ovos foram observados a fresco e morfologicamente avaliados quanto à maturidade sob microscópico óptico comum (aumento de 200 vezes). A classificação dos ovos em maduros e imaturos foi realizada de acordo com a metodologia proposta por Pellegrino e colaboradores (1962), sendo estabelecida a contagem de até 50 ovos por fragmento e os resultados expressos em porcentagem.

\subsubsection{Avaliação da peroxidação lipídica em amostras de fígado}

3.6.3.1 Determinação das substâncias reativas do ácido tiobarbitúrico (SRAT) presentes nas amostras de fígado

O objetivo da aplicação do método foi a determinação da concentração de SRAT em amostras do fígado dos animais experimentados. Para tanto, preparou-se um homogeneizado dos fígados com tampão fosfato (1:10 por grama de tecido), preservando as amostras às temperaturas entre 0 e $2{ }^{\circ} \mathrm{C}$. Logo após, as amostras foram centrifugadas a $3000 \mathrm{rpm}$, e o sobrenadante foi recolhido e armazenado à -80 ${ }^{\circ} \mathrm{C}$ até o momento da etapa a seguir.

\subsubsection{Dosagem do ácido tiobarbitúrico (TBA) nos homogeneizados}

Para a dosagem do TBA, pesou-se 0,5 gramas do sobrenadante, acondicionando-o em tubos de ensaio, em triplicata para cada amostra. Logo após, adicionou-se $50 \mu \mathrm{L}$ de solução etanólica de 2,6-bis(1,1-dimetiletil)-4-metilfenol) (BHT) a 4\% (p/v), 2,5 mL de ácido fosfórico a 1\% (v/v) e 1,25 mL de TBA a 1\% (p/v) em NaOH 0,05 M). Essa solução foi então aquecida em banho fervente por 15 min e resfriada em banho de gelo por $10 \mathrm{~min}$. 
Em seguida, adicionou-se $3 \mathrm{~mL}$ de butanol em cada tubo para que 0 complexo formado (TBA-MDA) passasse para a fase orgânica. Agitou-se os tubos lentamente (por 10 vezes) e esses foram levados à centrifugação a 4000 rpm por 3 $\min$.

Após a centrifugação, uma alíquota da fase butanólica (sobrenadante) de 200 $\mu \mathrm{L}$ foi retirada e plaqueada, em triplicata, em placa de ELISA para se fazer a leitura a $535 \mathrm{~nm}$ em espectrofotômetro.

Por fim, os dados de absorbância foram utilizados para se calcular a concentração do complexo TBA-MDA a partir da curva padrão de MDA previamente realizada.

\subsection{ANÁLISE ESTATÍSTICA}

No intuito de comparar os resultados obtidos das amostras independentes, o teste " $t$ " de Student e ANOVA foram aplicados. Os outliers foram retirados por aplicação do teste dos quadrados. Os resultados foram apresentados como média aritmética \pm 0 valor do desvio padrão e em porcentagem, considerando os valores significativamente diferentes quando $p<0,05$ por análise de variância one-way. A avaliação estatística dos resultados foi realizada utilizando os programas Excel e GraphPad Prism6®.

\subsection{ASPECTOS ÉTICOS}

Sob a observância dos Princípios Éticos da Experimentação Animal, a presente pesquisa foi submetida à apreciação do Comitê de ética para 0 uso de animais da FIOCRUZ (CEUA), tendo como número de aprovação LW 21/16. 


\section{RESULTADOS E DISCUSSÃO}

\subsection{ENSAIOS DE INIBIÇÃO DA ATIVIDADE ENZIMÁTICA DA APIRASE DA BATATA}

De acordo com os resultados ilustrados no gráfico 1 , o experimento que verifica a atividade ATPásica da apirase sugeriu que não havia uma diferença expressiva da atividade enzimática entre o grupo controle e os grupos do veículo nas três maiores concentrações. Já em relação ao ensaio para verificação da atividade ADPásica, esse apresentou maiores variações entre os grupos analisados, destacando-se uma possível influência da mistura de etanol e glicerol na atividade enzimática dos tubos que compõem o grupo controle veículo $0,1 \mathrm{mM}$.

\section{Gráfico 1 - Efeito do veículo sobre as atividades ATPásica e ADPásica da} NTPDase de Solanum tuberosum. O efeito do veículo sobre a atividade da enzima foi avaliado em comparação com o controle de água. O veículo, composto por uma mistura de $50 \% \mathrm{v} / \mathrm{v}$ glicerol PA e $50 \%$ etanol (5\%) preparado em água, foi testado nas três maiores concentrações equivalentes das drogas, em escala de $\mathrm{mM}$, sendo a atividade expressa em $n m o l P i . m g^{-1} \cdot \mathrm{min}^{-1}$.

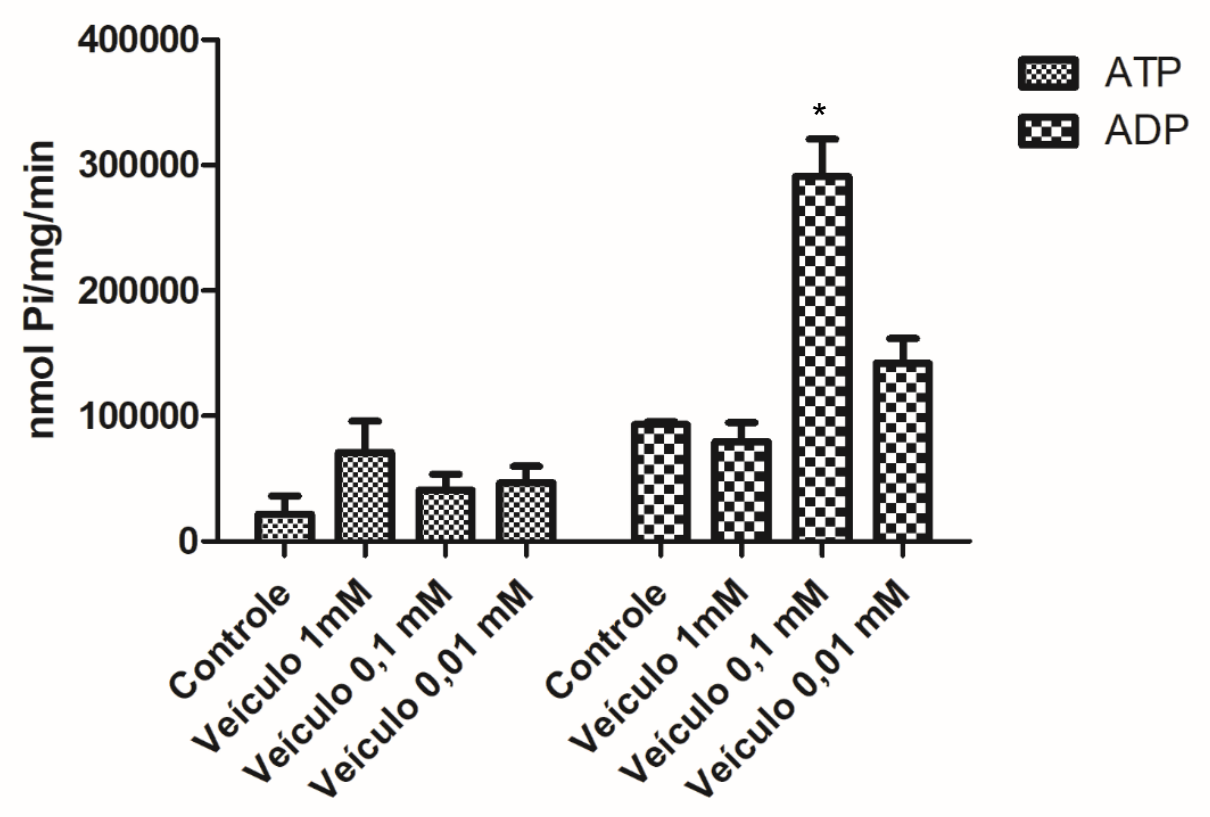

*Diferença significativa entre os demais grupos

Fonte: elaboração própria. 
Em relação ao experimente com droga LS23, verificou-se ausência de diferença na atividade enzimática quando comparados o controle de água e o controle veículo, se considerado a margem do desvio-padrão. Em relação aos grupos tratados com a droga LS23, comparando-se com os controles água e veículo, o experimento sugeriu que a essa droga não foi capaz de inibir a atividade enzimática da apirase na hidrólise do ATP ou ADP, em todas as concentrações testadas, como ilustra o gráfico 2.

\section{Gráfico 2 - Efeito da droga LS23 sobre as atividades ATPásica e ADPásica da} NTPDase de Solanum tuberosum. $O$ efeito de inibição de LS23 sobre a atividade da enzima, expressa em nmolPi. $\mathrm{mg}^{-1} \cdot \mathrm{min}^{-1}$, foi avaliado em comparação com o controle de água e controle veículo. O veículo, composto por uma mistura de $50 \%$ $\mathrm{v} / \mathrm{v}$ glicerol PA e $50 \%$ etanol (5\%) preparado em água, foi testado na maior concentração equivalente da droga. A droga foi testada em cinco concentrações (1 $\mathrm{mM}, 0,1 \mathrm{mM}, 0,01 \mathrm{mM}, 0,001 \mathrm{mM}$ e 0,0001 mM).

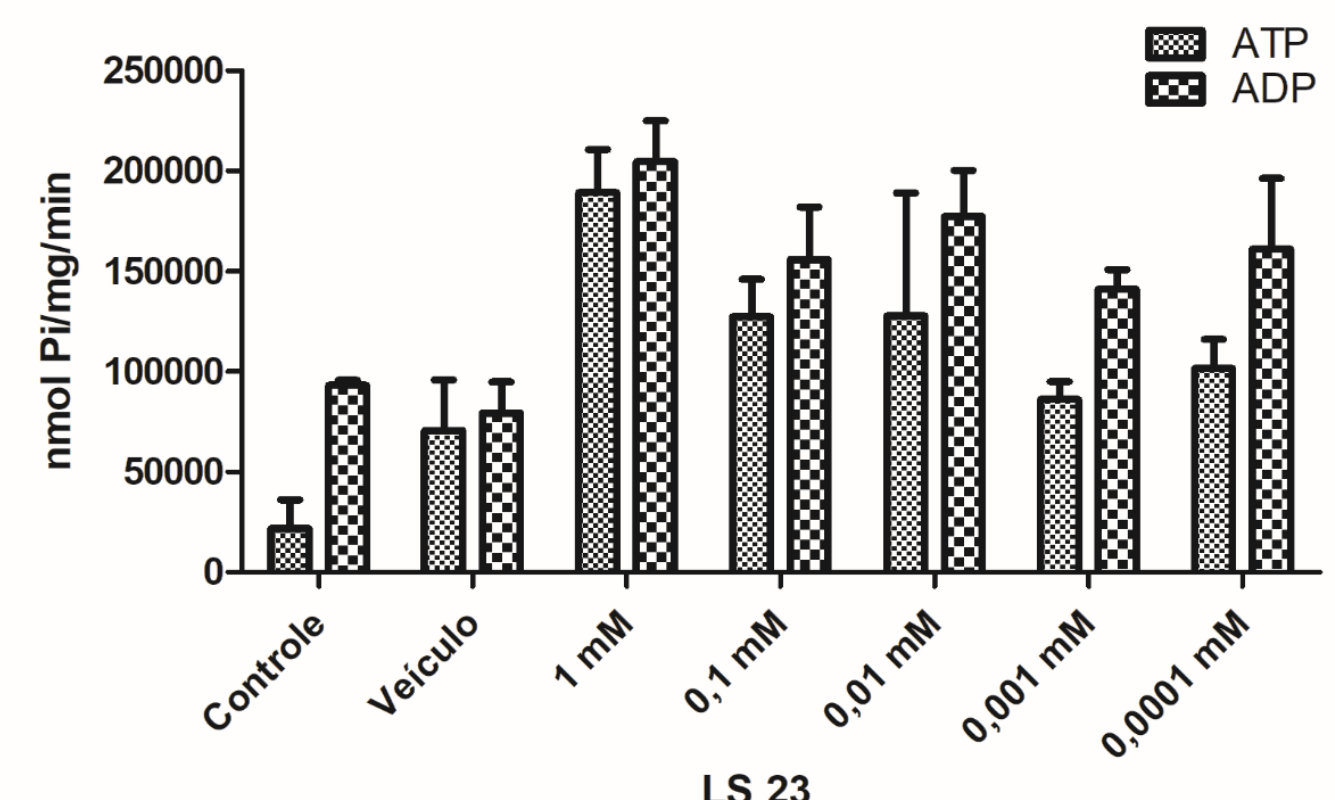

Fonte: elaboração própria.

Em relação à droga LS26, observa-se que a atividade do veículo e a atividade do controle água não diferem entre sim, tanto para análise da hidrolise do ATP quanto ADP. Ainda, observa-se uma redução da atividade ATPásica de 15, 12 e $47 \%$ nos grupos tratados com LS26 $(0,1 \mathrm{mM}, 0,001 \mathrm{mM}$ e $0,0001 \mathrm{mM}$, 
respectivamente) em relação ao controle de água. Já em relação à atividade ADPásica, o gráfico 3 sugere que os grupos tratados com a droga nas maiores concentrações aumentam um pouco a atividade enzimática basal (comparação com controle de água), tendendo a uma redução gradual da atividade nos grupos $0,01 \mathrm{mM}$ e $0,001 \mathrm{mM}(21,5 \%$ menor $)$.

\section{Gráfico 3 - Efeito da droga LS26 sobre as atividades ATPásica e ADPásica da} NTPDase de Solanum tuberosum. O efeito de inibição de LS26 sobre a atividade da enzima, expressa em nmolPi. $\mathrm{mg}^{-1} \cdot \mathrm{min}^{-1}$, foi avaliado em comparação com 0 controle de água e controle veículo. O veículo, composto por uma mistura de 50\% $\mathrm{v} / \mathrm{v}$ glicerol PA e $50 \%$ etanol (5\%) preparado em água, foi testado na maior concentração equivalente da droga. A droga foi testada em cinco concentrações (1 $\mathrm{mM}, 0,1 \mathrm{mM}, 0,01 \mathrm{mM}, 0,001 \mathrm{mM}$ e 0,0001 mM).

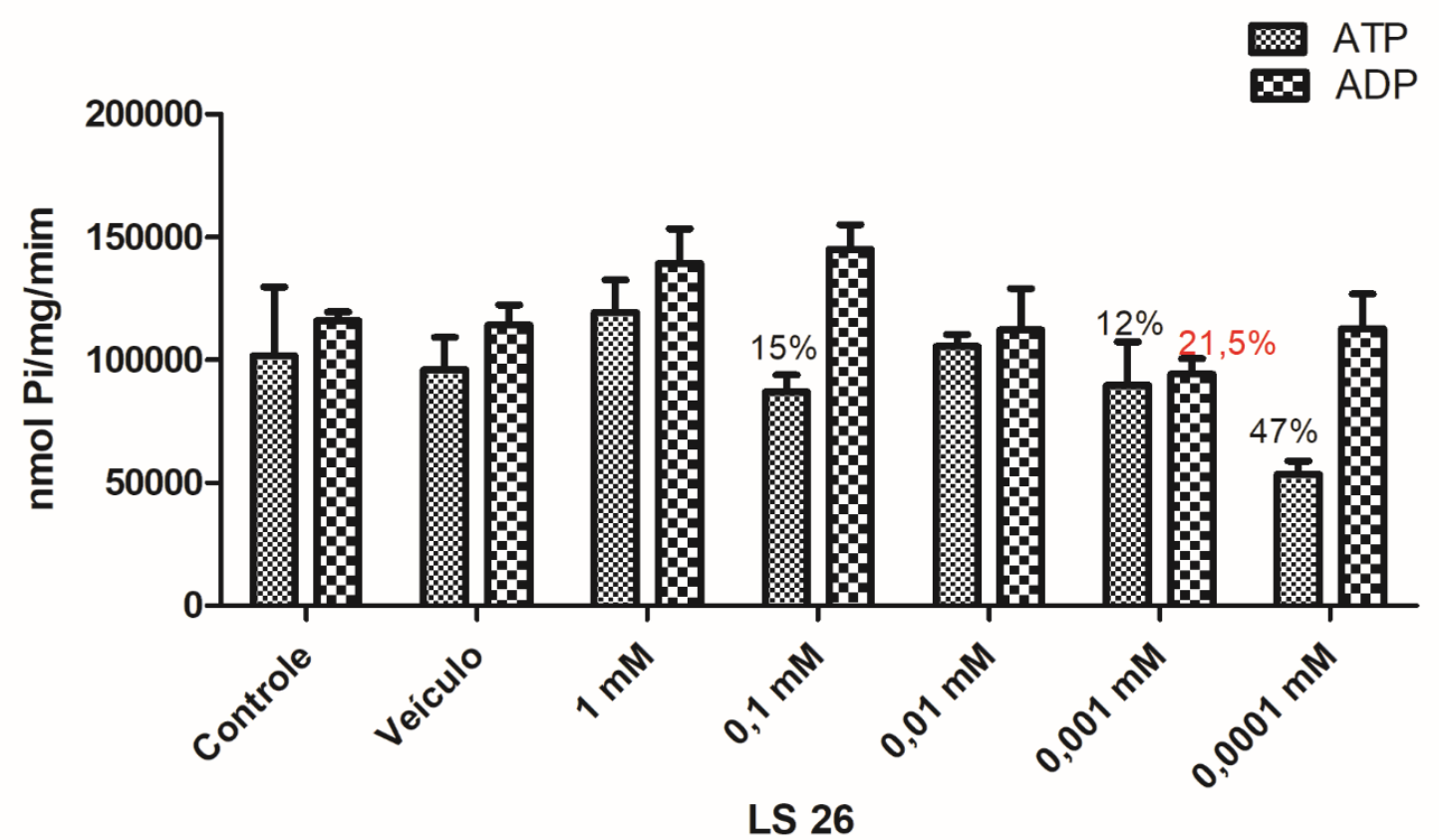

Fonte: elaboração própria.

Em relação à LS29, os experimentos revelaram um perfil de não-inibição da droga (gráfico 4) em relação à atividade basal dos controles. Esse achado corrobora com fator de não existência de inibidores disponíveis atualmente no mercado para esta família de enzimas. 


\section{Gráfico 4 - Efeito da droga LS29 sobre as atividades ATPásica e ADPásica da} NTPDase de Solanum tuberosum. O efeito de inibição de LS29 sobre a atividade da enzima, expressa em nmolPi.mg $\mathrm{mg}^{-1} \cdot \mathrm{min}^{-1}$, foi avaliado em comparação com o controle de água e controle veículo. O veículo, composto por uma mistura de 50\% $\mathrm{v} / \mathrm{v}$ glicerol PA e $50 \%$ etanol (5\%) preparado em água, foi testado na maior concentração equivalente da droga. A droga foi testada em cinco concentrações (1 $\mathrm{mM}, 0,1 \mathrm{mM}, 0,01 \mathrm{mM}, 0,001 \mathrm{mM}$ e 0,0001 mM).

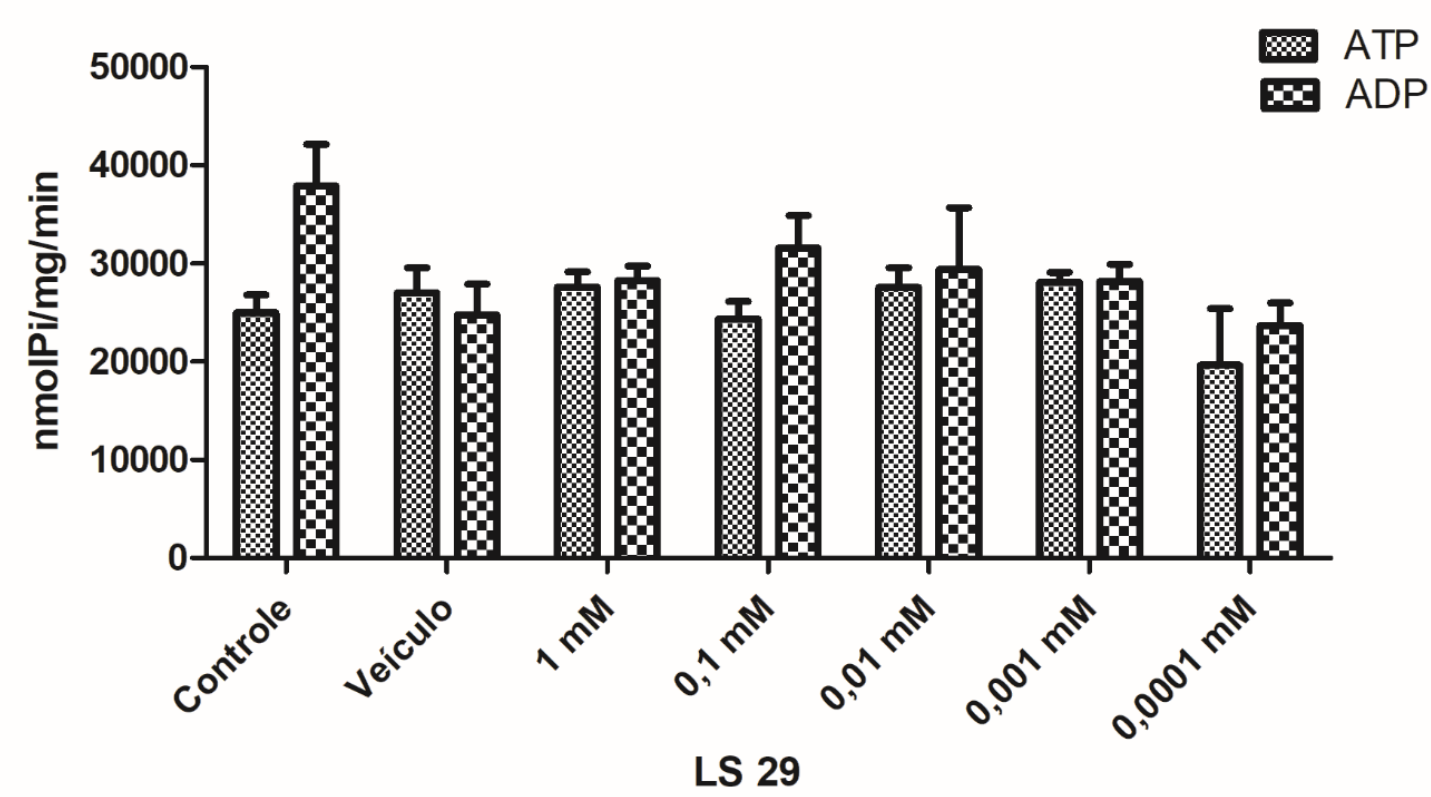

Fonte: elaboração própria.

4.2 ENSAIOS PARA AVALIAÇÃO DA INTEGRIDADE DE MEMBRANA E FORMAÇÃO DE AUTOFAGOSSOMOS USANDO MARCAÇÃO POR SONDAS FLUORESCENTES

As figuras a seguir ilustram os ensaios de marcação fluorescente pelas sondas monodansylcadaverine e dextrans, capazes de evidenciar a presença de autofagossomos e poros na membrada (integridade/permeabilidade) do verme, respectivamente. Nessas imagens, é possível observar a presença de pontos isolados de fluorescência ao longo do corpo dos vermes e também uma fluorescência mais contínua que corresponde à autofluorescência do próprio verme. Adicionalmente, nota-se que em todos os experimentos as fêmeas parecem 
absorver ambas as sondas mais intensamente que os machos, fenômeno ainda desconhecido.

Figura 7- Marcação de autofagossomos em vermes adultos de Schistosoma mansoni pela sonda fluorescente monodansylcadaverine após exposição à LS23 ou veículo por 24 horas. (a) Macho do controle veículo. (b) Fêmea do controle veículo. (c) Macho do grupo $25 \mu \mathrm{M}$. (d) Fêmea do grupo $25 \mu \mathrm{M}$. Os vermes foram incubados in vitro por 30 minutos com a sonda (20 ng/ml por poço) dissolvida em meio RPMI 1640, sendo lavados 3 vezes pela substituição do meio de cultura sobrenadante e posteriormente preparados para serem avaliados em microscópio de fluorescência, e fotografados.

Macho

(a)

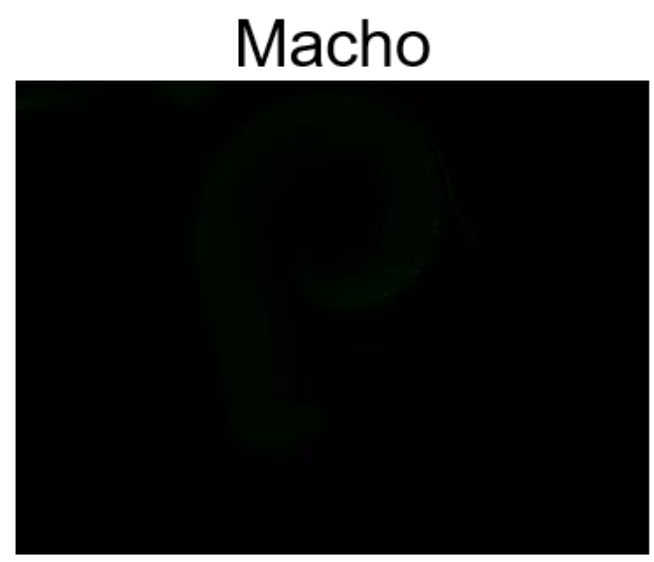

(c)

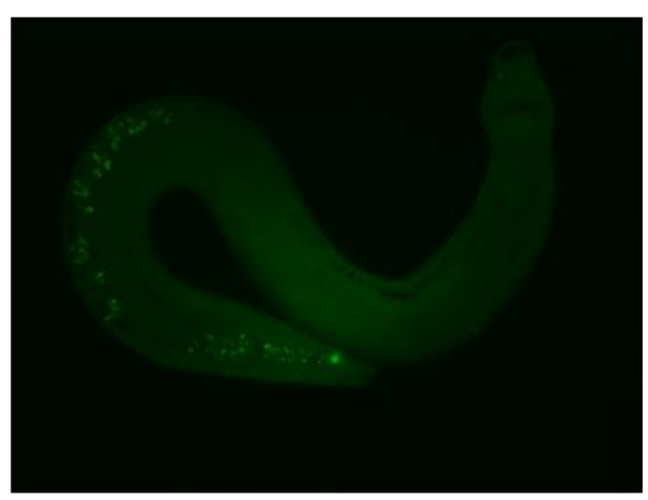

\section{Fêmea}

(b)

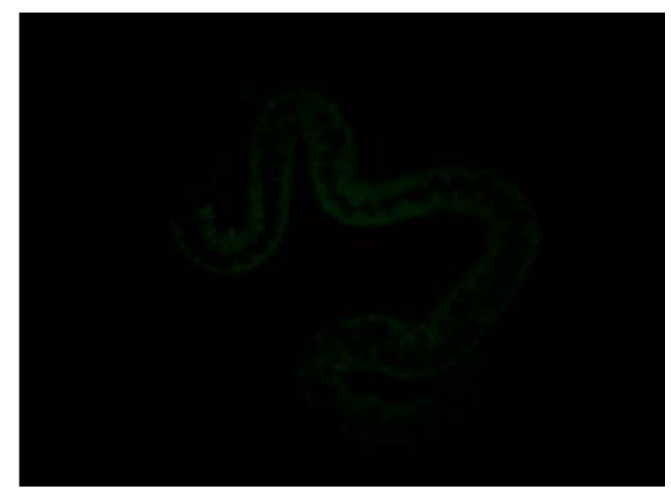

(d)

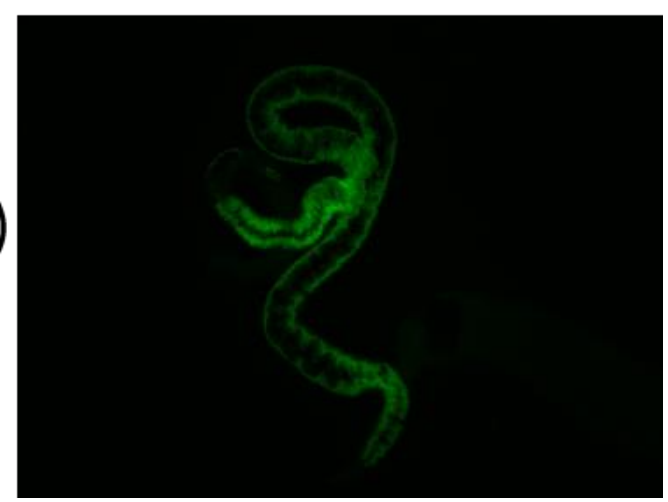

Fonte: elaboração própria. 
Figura 8- Marcação de poros (integridade/permeabilidade) no tegumento de vermes adultos de Schistosoma mansoni pelas sondas fluorescentes FITCDextrans após exposição à LS23 ou veículo por 24 horas. (a) Macho do controle veículo. (b) Fêmea do controle veículo. (c) Macho do grupo $25 \mu \mathrm{M}$. (d) aumento de 10x a figura "c". (e) Fêmea do grupo $25 \mu \mathrm{M}$. (f) aumento de 10x a figura "e". Os vermes foram incubados in vitro por 30 minutos com a sonda $(20 \mathrm{ng} / \mathrm{ml}$ por poço) dissolvida em meio RPMI 1640, sendo lavados 3 vezes pela substituição do meio de cultura sobrenadante e posteriormente preparados para serem avaliados em microscópio de fluorescência, e fotografados.

Macho

(a)

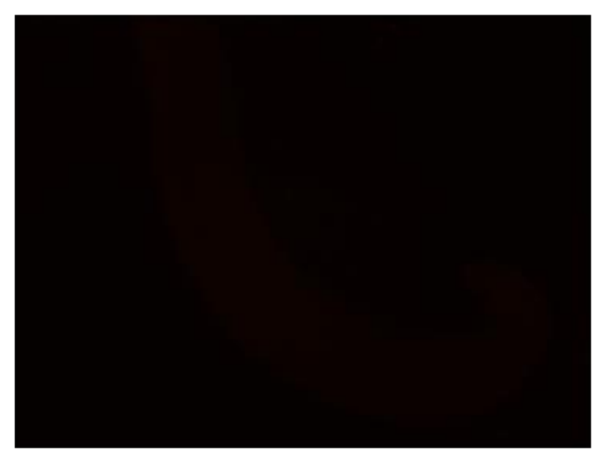

(c)

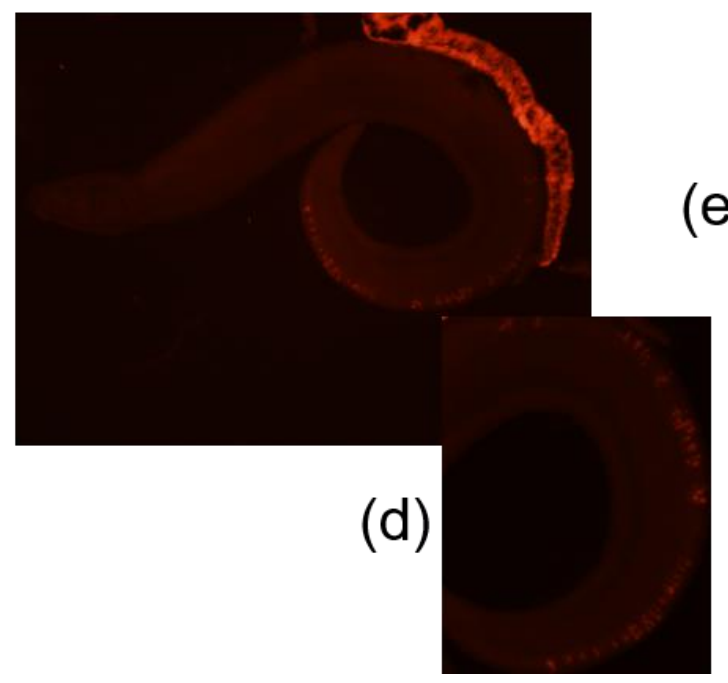

\section{Fêmea}

(b)

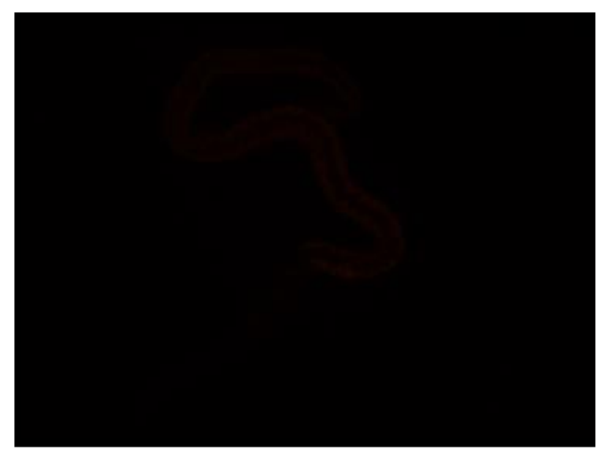

(e)

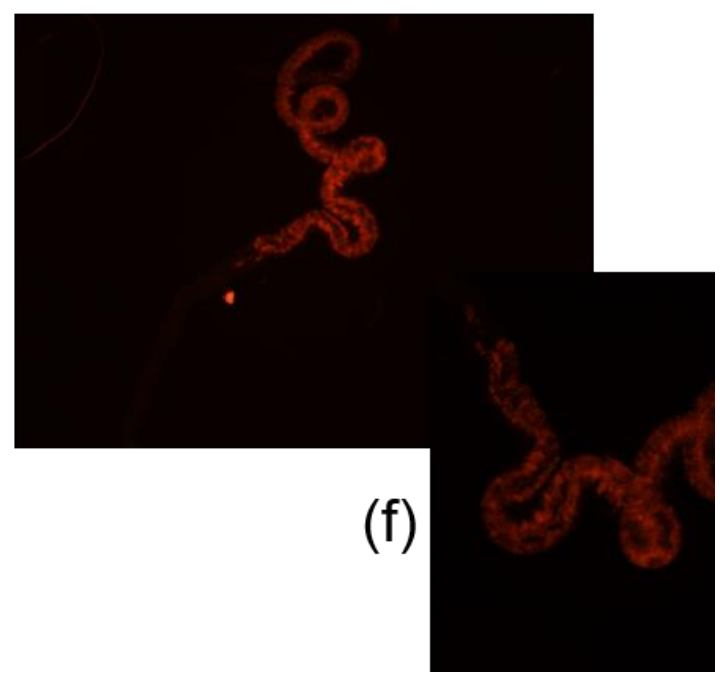

Fonte: elaboração própria. 
Figura 9- Marcação de autofagossomos em vermes adultos de Schistosoma mansoni pela sonda fluorescente monodansylcadaverine após exposição à LS26 ou veículo por 24 horas. (a) Macho do controle veículo. (b) Fêmea do controle veículo. (c) Macho do grupo $25 \mu \mathrm{M}$. (d) Fêmea do grupo $10 \mu \mathrm{M}$. (e) aumento de 10x a figura "d". Os vermes foram incubados in vitro por 30 minutos com a sonda (20 ng/ml por poço) dissolvida em meio RPMI 1640, sendo lavados 3 vezes pela substituição do meio de cultura sobrenadante e posteriormente preparados para serem avaliados em microscópio de fluorescência, e fotografados.

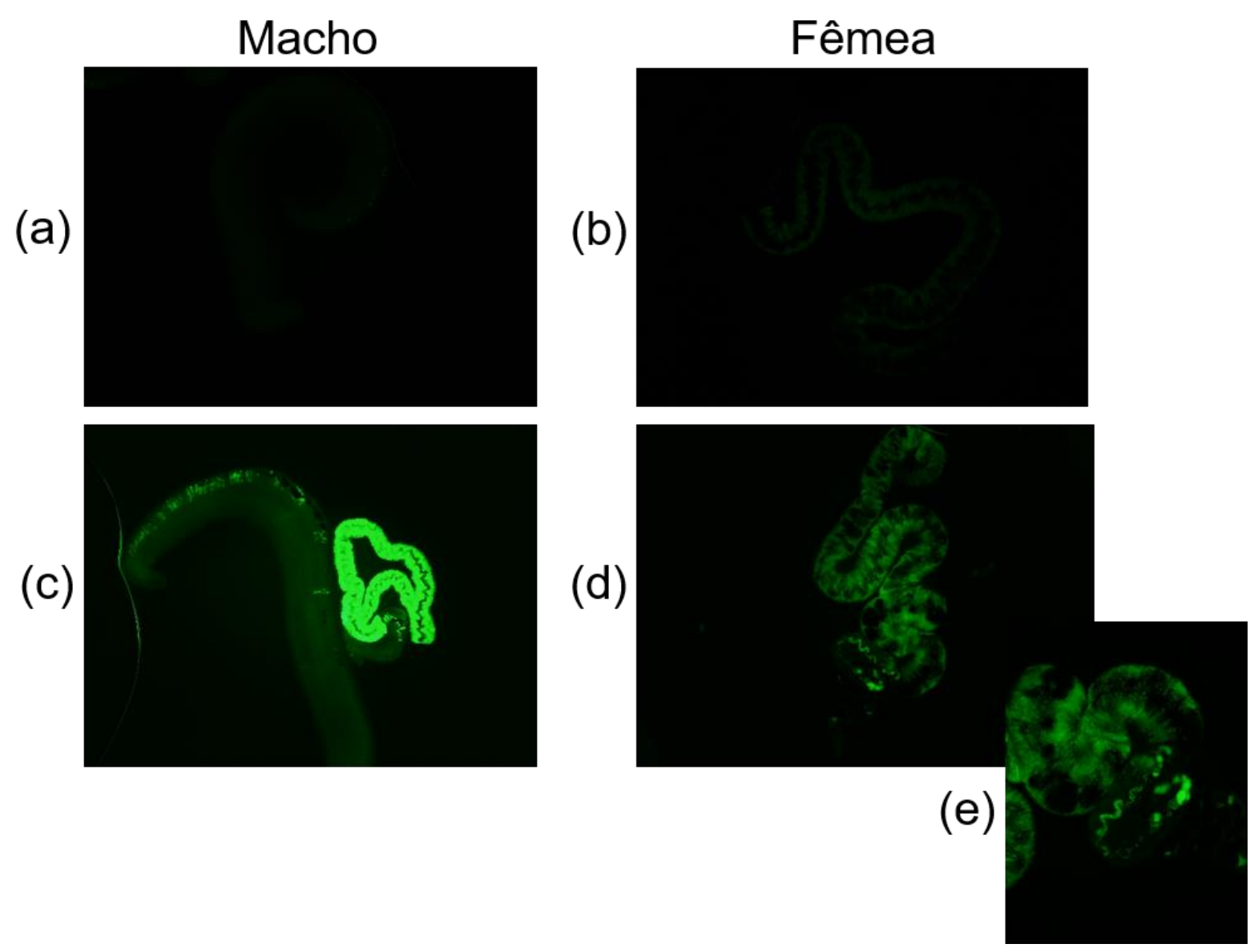

Fonte: elaboração própria. 
Figura 10- Marcação de poros (integridade/permeabilidade) no tegumento de vermes adultos de Schistosoma mansoni pelas sondas fluorescentes FITCDextrans após exposição à LS26 ou veículo por 24 horas. (a) Macho do controle veículo. (b) Fêmea do controle veículo. (c) Macho do grupo $25 \mu \mathrm{M}$. (d) Fêmea do grupo $25 \mu \mathrm{M}$. Os vermes foram incubados in vitro por 30 minutos com a sonda (20 $\mathrm{ng} / \mathrm{ml}$ por poço) dissolvida em meio RPMI 1640, sendo lavados 3 vezes pela substituição do meio de cultura sobrenadante e posteriormente preparados para serem avaliados em microscópio de fluorescência, e fotografados.
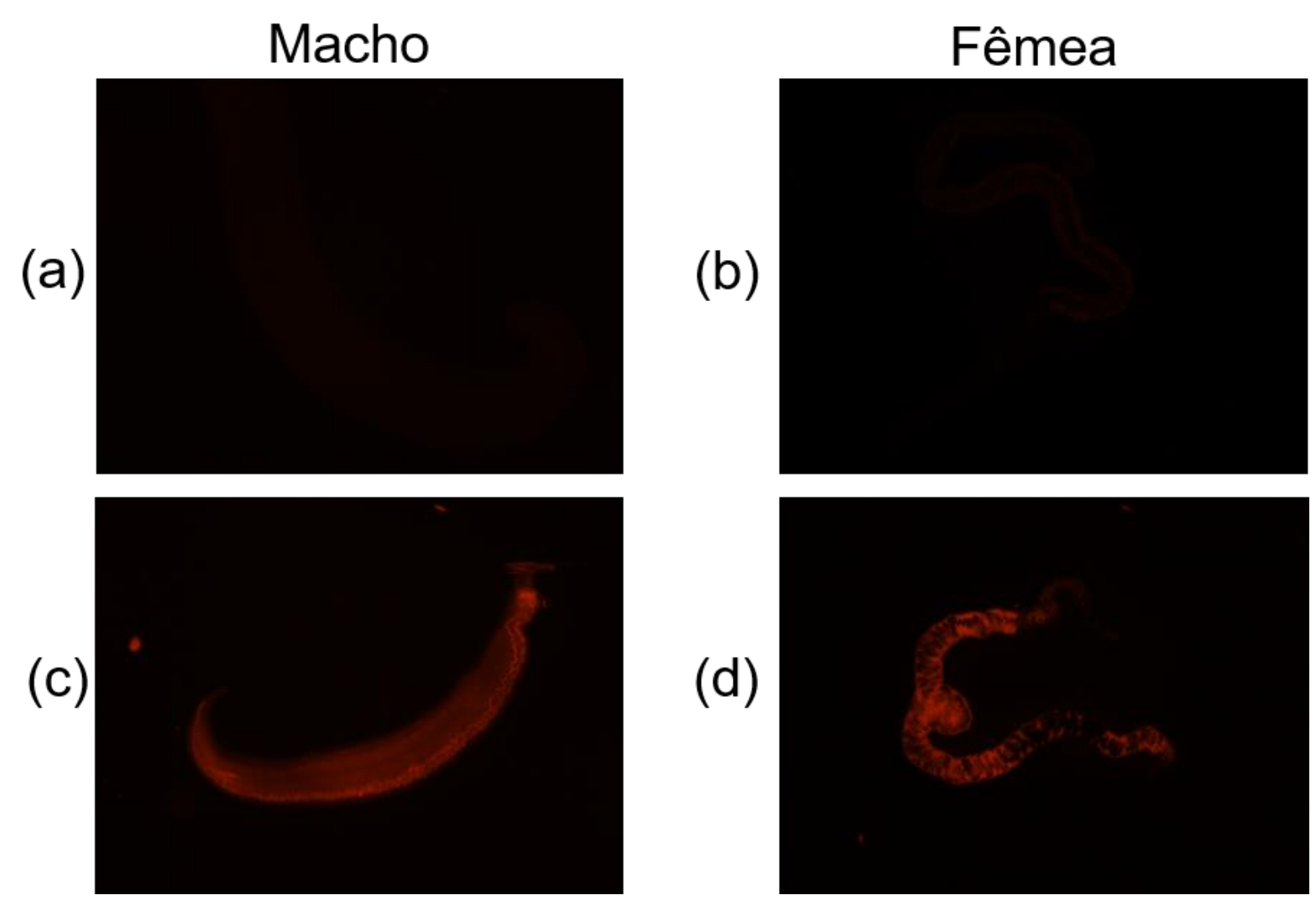

Fonte: elaboração própria. 
Figura 11- Marcação de autofagossomos em vermes adultos de Schistosoma mansoni pela sonda fluorescente monodansylcadaverine após exposição à LS29 ou veículo por 24 horas. (a) Macho do controle veículo. (b) Fêmea do controle veículo. (c) Macho do grupo $10 \mu \mathrm{M}$. (d) Fêmea do grupo $10 \mu \mathrm{M}$. (e) aumento de 10x a figura "d". Os vermes foram incubados in vitro por 30 minutos com a sonda (20 ng/ml por poço) dissolvida em meio RPMI 1640, sendo lavados 3 vezes pela substituição do meio de cultura sobrenadante e posteriormente preparados para serem avaliados em microscópio de fluorescência, e fotografados.

\section{Macho}

(a)

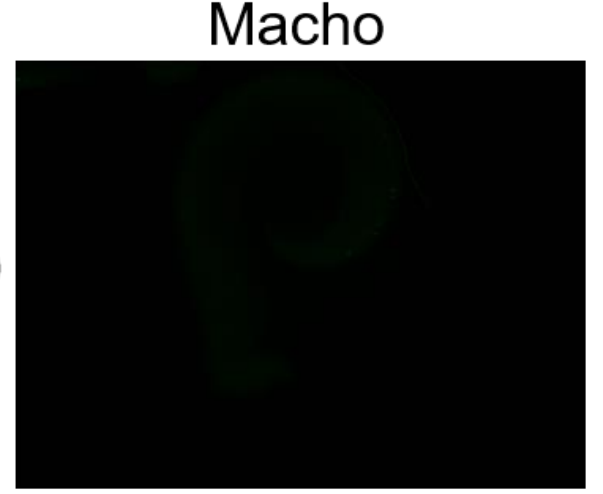

(c)

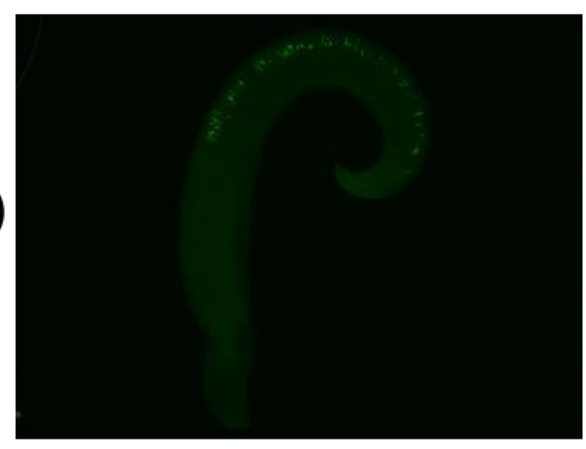

Fêmea

(b)
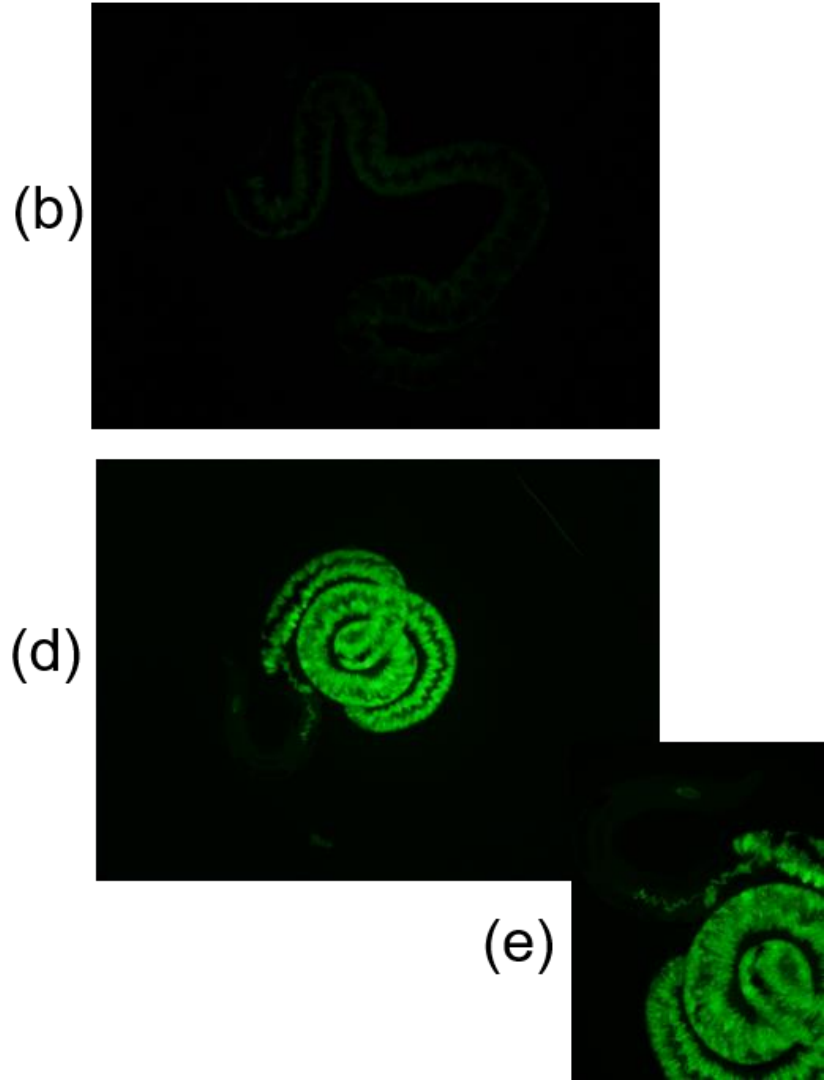

Fonte: elaboração própria. 
Figura 12- Marcação de poros (integridade/permeabilidade) no tegumento de vermes adultos de Schistosoma mansoni pelas sondas fluorescentes FITCDextrans após exposição à LS29 ou veículo por 24 horas. (a) Macho do controle veículo. (b) Fêmea do controle veículo. (c) Macho do grupo $10 \mu \mathrm{M}$. (d) Fêmea do grupo $10 \mu \mathrm{M}$. (e) aumento de 10x a figura "d". Os vermes foram incubados in vitro por 30 minutos com a sonda (20 ng/ml por poço) dissolvida em meio RPMI 1640, sendo lavados 3 vezes pela substituição do meio de cultura sobrenadante e posteriormente preparados para serem avaliados em microscópio de fluorescência, e fotografados.
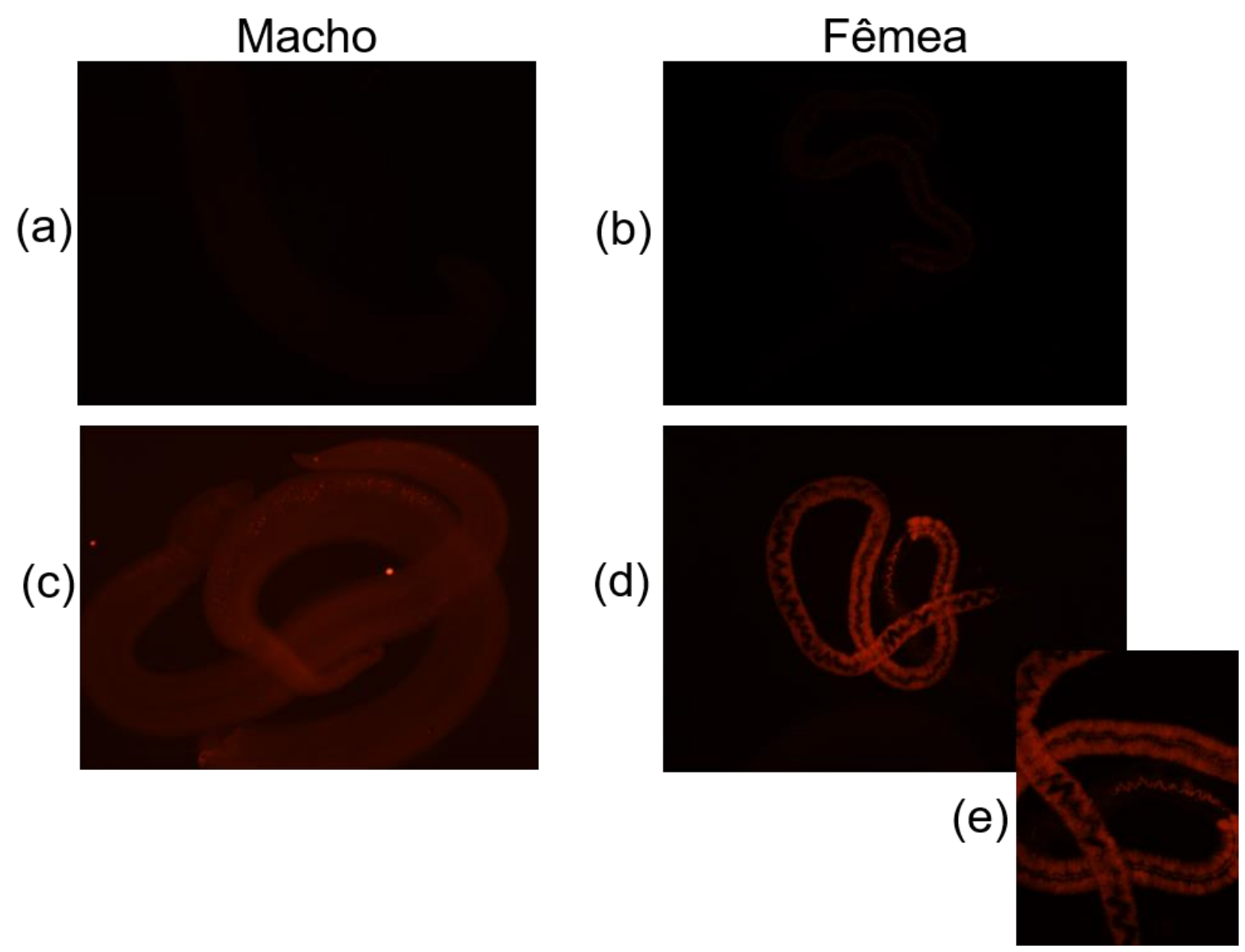

Fonte: elaboração própria. 


\subsection{ENSAIOS IN VIVO}

\subsubsection{Recuperação de vermes}

A verificação da redução do número de verme e a distribuição desses entre mesentério e fígado, aliados às alterações no oograma, juntos constituem os principais métodos para a triagem de drogas esquistossomicidas (PELLEGRINO; KATZ, 1968).

A literatura relata que, em camundongos experimentalmente infectados com $S$. mansoni, existe uma determinada porcentagem de distribuição dos vermes, aos 45 dias pós infecção, quando quase todos eles já atingiram a maturidade sexual e iniciaram a postura de ovos: $60 \%-70 \%$ encontram-se nos vasos mesentéricos; $20 \%$ $30 \%$ na veia porta e $0 \%-20 \%$ nas veias intra-hepáticas. Ainda, quando ocorre a administração de uma droga ativa, essa tende a causar um deslocamento parcial ou total dos vermes para o fígado (PELLEGRINO; KATZ, 1968). Baseando-se nisso, por meio da perfusão dos vasos sanguíneos dos camundongos infectados é possível fazer a recuperação dos vermes, contá-los, separá-los em machos e fêmeas, identificar o local onde estão distribuídos, enfim, levantar várias informações do modelo experimental que irão indicar o potencial de atividade esquistossomicida de novas drogas.

Nos experimentos que realizamos, tanto a droga LS26 quanto a LS29 mostraram-se efetivas na redução da carga parasitária (total de vermes adultos recuperados), estando os dados compilados nos gráficos 1 e 2 e nas tabelas 1 e 2 . 
Gráfico 5 - Distribuição da carga parasitária nos grupos de animais não tratados, tratados com praziquantel (PZQ) e grupos tratados com a droga LS26 em diferentes esquemas terapêuticos. A carga parasitária representa a média do número de vermes (machos e fêmeas) recuperados dos animais. Os camundongos foram divididos em seis grupos experimentais, incluindo um grupo controle não tratado e um grupo controle tratado com praziquantel $200 \mathrm{mg} / \mathrm{Kg}$ de peso, por via oral, como controle positivo do experimento. Os demais grupos receberam a droga teste LS26 também por via oral nas doses $50 \mathrm{mg} / \mathrm{Kg}$ ou $100 \mathrm{mg} / \mathrm{Kg}$ de peso, em dois esquemas distintos: dose única (DU) e duas doses (2D), sendo o último intercalado por um período de 10 dias.

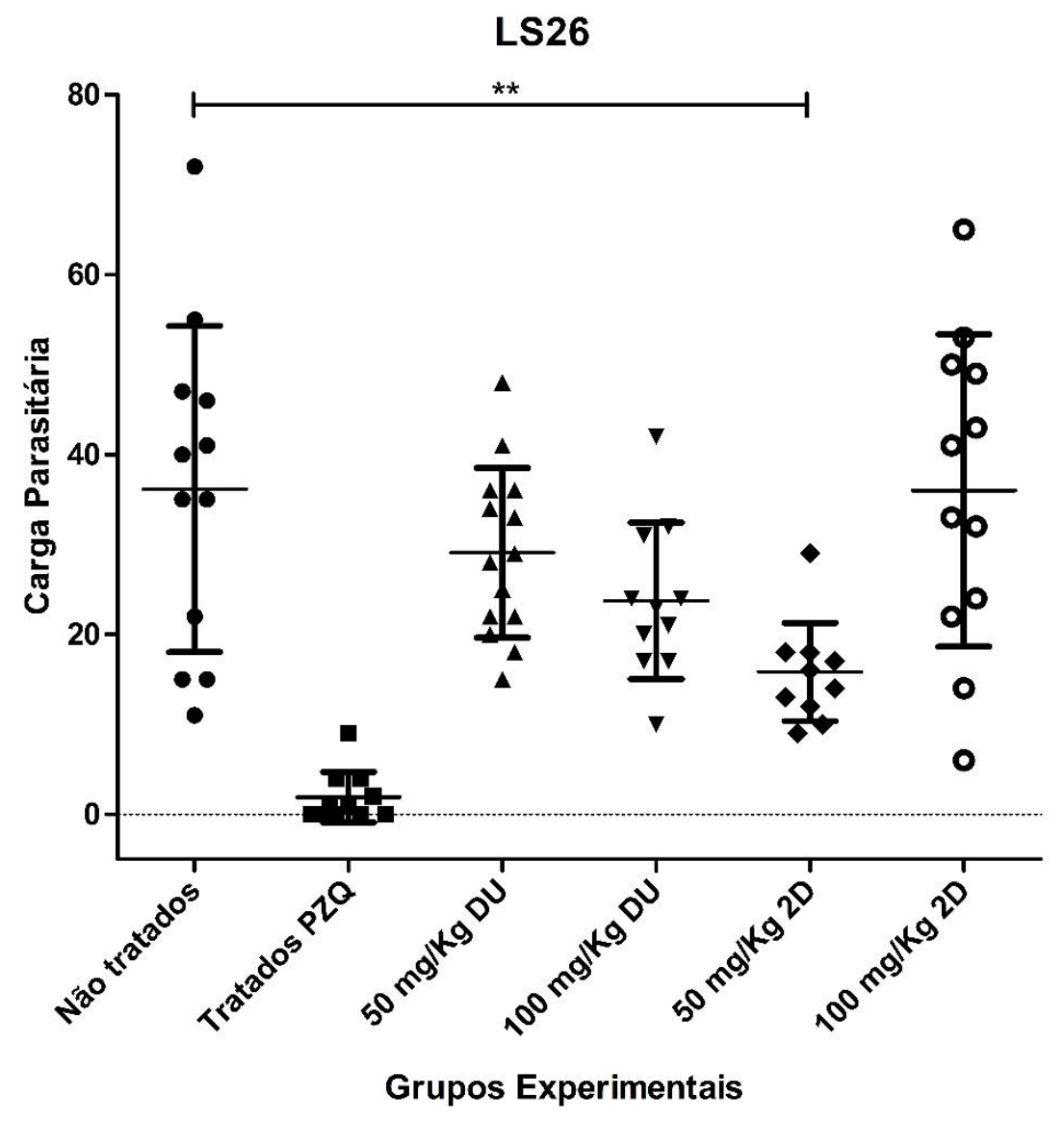

** Diferença significativa $(p<0,0018)$ entre o grupo não tratado e o grupo tratado com LS26 $50 \mathrm{mg} / \mathrm{Kg}$, em esquema de duas doses.

Fonte: elaboração própria.

Os resultados dos tratamentos com LS26 sugerem uma forte atividade esquistossomicida dessa droga na concentração de $50 \mathrm{mg} / \mathrm{Kg}$ em esquema 
terapêutico de duas doses, onde neste grupo houve uma redução da carga parasitária de 56.20\% em comparação ao controle não tratado.

Em relação à distribuição percentual entre veias mesentéricas e os vasos hepáticos, LS26, no mesmo esquema terapêutico referido anteriormente, foi capaz de causar um aumento significativo no deslocamento parcial dos vermes que habitavam as veias mesentéricas, quando comparado ao controle não tratado, o que reforça ainda mais o caráter de droga ativa sobre os vermes adultos de $S$. mansoni. Adicionalmente, a tabela 1 ilustra que o mesmo fenômeno do aumento do deslocamento parcial também ocorreu nos grupos que receberam o tratamento com LS26 100 mg/Kg em dose única.

Tabela 1 - Taxas de recuperação dos vermes adultos de Schistosoma mansoni, expressas em média e desvio padrão (DP), e distribuição percentual, em relação à média, encontradas no mesentério e fígado dos grupos de animais não tratados, tratados com praziquantel (PZQ) e grupos tratados com a droga LS26 em diferentes esquemas terapêuticos. Os camundongos foram divididos em seis grupos experimentais, incluindo um grupo controle não tratado e um grupo controle tratados com praziquantel $200 \mathrm{mg} / \mathrm{Kg}$ de peso, por via oral, como controle positivo do tratamento. Os demais grupos receberam a droga teste LS26 também por via oral nas doses $50 \mathrm{mg} / \mathrm{Kg}$ ou $100 \mathrm{mg} / \mathrm{Kg}$ de peso, em dois esquemas distintos: dose única (DU) e duas doses (2D), sendo o último intercalado por um período de 10 dias.

\begin{tabular}{cccccc}
\hline $\begin{array}{c}\text { Esquema de } \\
\text { tratamento }\end{array}$ & $\begin{array}{c}\text { Animais } \\
\text { experimentados }\end{array}$ & \multicolumn{2}{c}{ Média de vermes } & \multicolumn{2}{c}{ Distribuição de vermes } \\
\cline { 4 - 6 } mg/Kg & $\mathbf{n}^{\circ}$ & + DP (\% redução) & Mesentério & Fígado \\
\hline Não tratados & 12 & $36,17 \pm 18,15$ & 88,48 & 11,52 \\
Tratados PZQ & 11 & $1,90 \pm 2,81(94,74)^{a}$ & $76,32^{a}$ & $23,68^{a}$ \\
Dose Única 50 & 14 & $29,07 \pm 9,43(19,63)$ & 79,36 & 20,64 \\
Dose Única 100 & 11 & $23,73 \pm 8,70(34,39)$ & $63,21^{a}$ & 36,79 \\
Duas Doses 50 & 11 & $15,82 \pm 5,44(56,16)^{a}$ & $82,74^{a}$ & 17,26 \\
Duas Doses 100 & 12 & $36,00 \pm 17,37(0,47)$ & 88,00 & 12,00 \\
\hline
\end{tabular}

a: Diferença significativa em relação ao grupo controle não tratados $(p<0,05)$

Fonte: elaboração própria.

Em relação aos tratamentos com LS29, os resultados foram ainda mais instigantes, pois essa droga conseguiu reduzir a carga global parasitária de forma 
significativa em duas propostas terapêuticas: no grupo tratado com $50 \mathrm{mg} / \mathrm{Kg}$ em duas doses notou-se uma redução percentual de $57,61 \%$ do total de vermes, e no grupo tratado com $100 \mathrm{mg} / \mathrm{Kg}$ em duas doses também houve uma redução significativa de $37,15 \%$, ambas em relação ao grupo controle não tratado (gráfico 9).

Gráfico 6 - Distribuição da carga parasitária nos grupos de animais não tratados, tratados com praziquantel (PZQ) e grupos tratados com a droga LS29 em diferentes esquemas terapêuticos. A carga parasitaria representa a média do número de vermes (machos e fêmeas) recuperados dos animais. Os camundongos foram divididos em seis grupos experimentais, incluindo um grupo controle não tratado e um grupo controle tratados com praziquantel $200 \mathrm{mg} / \mathrm{Kg}$ de peso, por via oral, como controle positivo do tratamento. Os demais grupos receberam a droga teste LS29 também por via oral nas doses $50 \mathrm{mg} / \mathrm{Kg}$ ou $100 \mathrm{mg} / \mathrm{Kg}$ de peso, em dois esquemas distintos: dose única (DU) e duas doses (2D), sendo o último intercalado por um período de 10 dias.

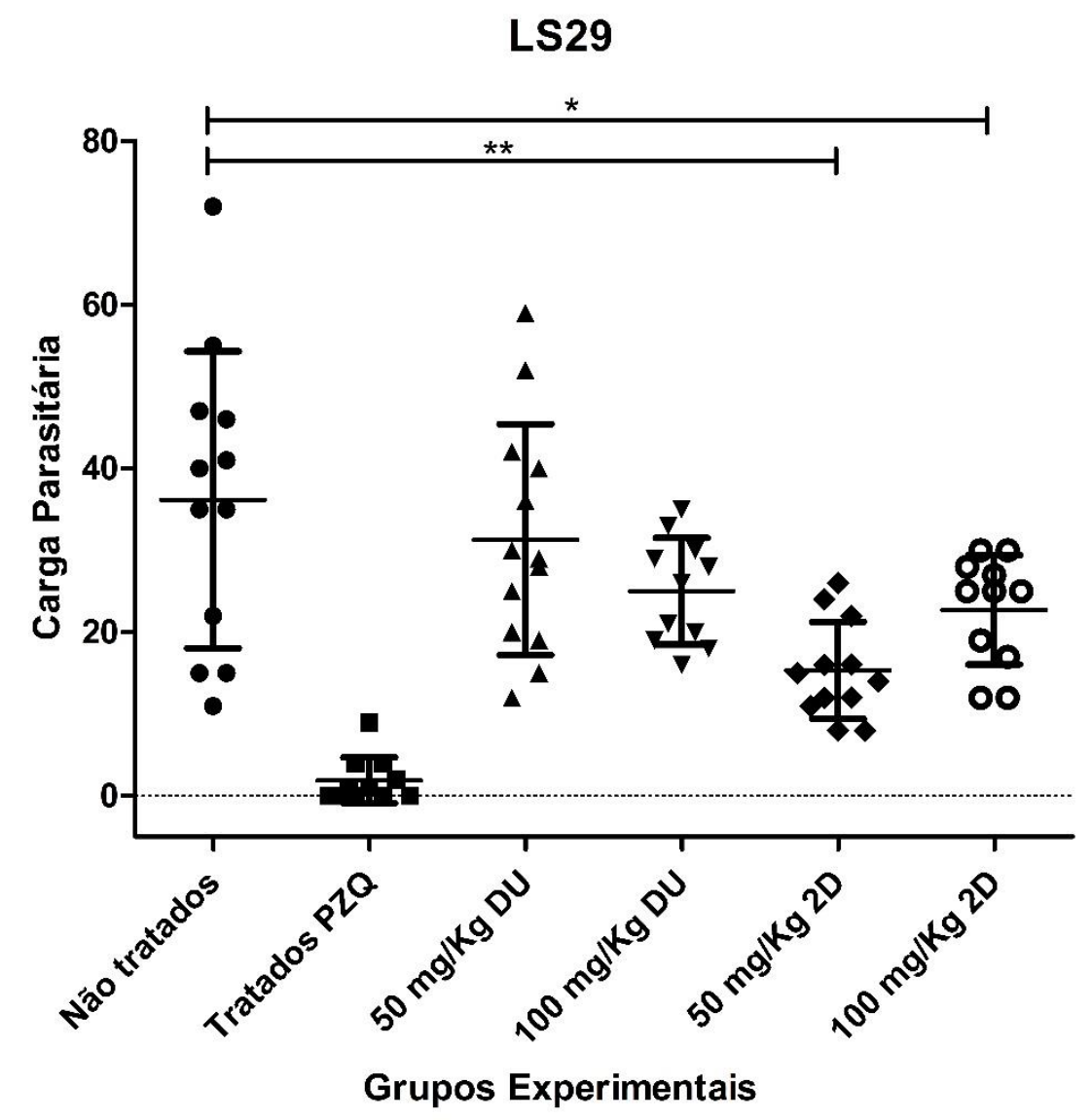


* Diferença significativa $(p<0,05)$ entre o grupo não tratado e o grupo tratado com LS29 $100 \mathrm{mg} / \mathrm{Kg}$, em esquema de duas doses.

** Diferença significativa $(p<0,001)$ entre o grupo não tratado e o grupo tratado com LS29 $100 \mathrm{mg} / \mathrm{Kg}$, em esquema de duas doses.

Fonte: elaboração própria.

Por sua vez, a droga LS29 também foi capaz de causar aumento significativo no deslocamento parcial dos vermes outrora albergados nas veias mesentéricas, tanto no esquema terapêutico de $50 \mathrm{mg} / \mathrm{Kg}$ em duas doses quanto no de $100 \mathrm{mg} / \mathrm{Kg}$ em duas doses (tabela 2).

Tabela 2 - Taxas de recuperação dos vermes adultos de Schistosoma mansoni, expressas em média e desvio padrão (DP), e distribuição percentual, em relação à média, encontradas no mesentério e fígado dos grupos de animais não tratados, tratados com praziquantel (PZQ) e grupos tratados com a droga LS29 em diferentes esquemas terapêuticos. Os camundongos foram divididos em seis grupos experimentais, incluindo um grupo controle não tratado e um grupo controle tratados com praziquantel $200 \mathrm{mg} / \mathrm{Kg}$ de peso, por via oral, como controle positivo do tratamento. Os demais grupos receberam a droga teste LS29 também por via oral nas doses $50 \mathrm{mg} / \mathrm{Kg}$ ou $100 \mathrm{mg} / \mathrm{Kg}$ de peso, em dois esquemas distintos: dose única (DU) e duas doses (2D), sendo o último intercalado por um período de 10 dias.

\begin{tabular}{cccccc}
\hline $\begin{array}{c}\text { Esquema de } \\
\text { tratamento }\end{array}$ & $\begin{array}{c}\text { Animais } \\
\text { experimentados }\end{array}$ & \multicolumn{3}{c}{ Média de vermes } & \multicolumn{2}{c}{ Distribuição de vermes } \\
\cline { 4 - 6 } mg/Kg & $\mathbf{n}^{\circ}$ & + DP (\% redução) & Mesentério & Fígado \\
\hline Não tratados & 12 & $36,17 \pm 18,15$ & 88,48 & 11,52 \\
Tratados PZQ & 11 & $1,90 \pm 2,81(94,74)^{a}$ & $76,32^{a}$ & $23,68^{a}$ \\
Dose Única 50 & 13 & $31,31 \pm 14,10(13,45)$ & 88,69 & 11,31 \\
Dose Única 100 & 11 & $25,00 \pm 6,50(30,88)$ & 81,82 & 18,18 \\
Duas Doses 50 & 12 & $15,33 \pm 5,91(57,61)^{a}$ & $85,87^{a}$ & 14,13 \\
Duas Doses 100 & 11 & $22,73 \pm 6,70(37,15)^{a}$ & $87,60^{a}$ & 12,40 \\
\hline
\end{tabular}

a: Diferença significativa em relação ao grupo controle não tratados $(p<0,05)$

Fonte: elaboração própria. 
De maneira geral, em relação à redução global da carga parasitária, as duas drogas pareceram ser mais efetivas quando trabalhadas no esquema terapêutico de $50 \mathrm{mg} / \mathrm{Kg}$ em duas doses.

De forma curiosa, na proposta terapêutica de $100 \mathrm{mg} / \mathrm{Kg}$ em duas doses para LS29, apesar de se ter notado uma redução significativa da carga parasitária em relação ao grupo controle não tratado, quando comparamos ao esquema de 50 $\mathrm{mg} / \mathrm{Kg}$ em duas doses, a redução foi menor na média de vermes recuperados. Assim, o experimento revelou que quando trabalhamos com duas doses, não temos necessariamente um perfil em que com o aumento da dose aumenta-se a resposta (ou seja, aumento da redução da carga de parasitos). De qualquer modo, por não se conhecer ainda o perfil farmacocinético dessa droga, pouco se pode inferir sobre esse achado.

\subsubsection{Análise qualitativa e quantitativa do oograma}

Para Katz (2008), o estudo do oograma deve ser um método preposto para mavaliação de triagem de drogas e também constar sempre nos ensaios não clínicos de agentes ativos contra S. mansoni. Assim, para efeitos do estudo do oograma considera-se que, nas infecções experimentais, a partir do trigésimo dia de inoculação os vermes fêmeas iniciam a postura de ovos ainda imaturos, que levam em torno de seis dias para o amadurecimento completo, ou seja, para que o embrião de primeiro estágio atinja a forma de miracídeo. Nesse método, portanto, fragmentos de intestino delgado são levados ao microscópico para uma análise morfológica dos ovos, o que permite a classificação entre viáveis (com presença do embrião) ou mortos. Dentre os ovos viáveis ocorrem os maduros (com o miracídio totalmente desenvolvido) e os imaturos (primeiro estágio: o embrião ocupa menos de 1/3 do diâmetro do ovo; segundo estágio: metade do diâmetro; terceiro estágio: 2/3 do comprimento do ovo; quarto estágio: praticamente todo o ovo é ocupado pelo embrião).

Pellegrino e Katz (1968), examinando fragmentos de intestino delgado de camundongos infectados e tratados com uma droga ativa contra vermes adultos de S. mansoni, verificaram que com o passar dos dias após o tratamento, os ovos dos estágios iniciais foram desaparecendo gradativamente, visto que no sétimo dia os ovos de quarto estágio não eram mais achados; já em relação aos ovos maduros, foi 
verificado que esses poderiam persistir por até mais de 12 dias na parede intestinal. Seguindo essa linha de pensamento, uma análise do oograma dos animais experimentados e tratados com uma determinada droga permitiria então a verificação do fenômeno de interrupção da postura.

Nesse sentido, para verificar o efeito das drogas LS26 e LS29 sobre o oograma, adotou-se a metodologia da contagem dos ovos viáveis presentes nos fragmentos de intestino delgado dos animais experimentados, classificando os ovos em maduros e imaturos (nos quatro estágios). Ainda, o oograma foi considerado alterado na ausência de um ou mais estágios imaturos (ARAÚJO et al., 1996). Os resultados obtidos com esse experimento estão mostrados nas tabelas 3 e 4 .

Tabela 3 - Distribuição percentual dos ovos viáveis encontrados nos fragmentos de intestino delgado de animais infectados por Schistosoma mansoni submetidos a diferentes tratamentos com LS26 ou PZQ e classificação do estado do oograma.

\begin{tabular}{cccccccc}
\hline \multirow{2}{*}{$\begin{array}{c}\text { Esquema de } \\
\text { tratamento }\end{array}$} & $\begin{array}{c}\text { Ovos } \\
\text { Maduros }\end{array}$ & \multicolumn{4}{c}{ Ovos Imaturos (\%) } & & \multirow{2}{*}{$\begin{array}{c}\text { Alteração de } \\
\text { oograma }\end{array}$} \\
\cline { 3 - 6 } (mg $\mathbf{K g})$ & $\mathbf{( \% )}$ & IV & III & II & I & \\
\hline Sem tratamento & 55,77 & 12,67 & 16 & 4,78 & 10,22 & Não \\
Controle PZQ & $91,59^{a}$ & $0,93^{a}$ & $0,93^{a}$ & $0,93^{a}$ & $5,6^{a}$ & Sim \\
Dose Única 50 & $67,54^{b}$ & $11,45^{b}$ & $5,01^{a b}$ & $5,96^{b}$ & 10,02 & Sim \\
Dose Única 100 & 44,39 & $19,39^{b}$ & $7,94^{b}$ & $6,07^{b}$ & $22,2^{b}$ & Sim \\
Duas Doses 50 & 55,33 & $17^{a b}$ & $7,61^{a b}$ & $8,12^{b}$ & $11,92^{b}$ & Sim \\
Duas Doses 100 & $79,28^{b}$ & $9,31^{b}$ & $2,1^{a}$ & 4,5 & $4,8^{a}$ & Sim \\
\hline
\end{tabular}

a: Diferença significativa em relação ao grupo controle não tratados $(p<0,05)$;

b: Diferença significativa em relação ao grupo controle $P Z Q(p<0,05)$.

Fonte: elaboração própria. 
Tabela 4 - Distribuição percentual dos ovos viáveis encontrados nos fragmentos de intestino delgado de animais infectados por Schistosoma mansoni submetidos a diferentes tratamentos com LS29 ou PZQ e classificação do estado do oograma.

\begin{tabular}{ccccccc}
\hline \multirow{2}{*}{$\begin{array}{c}\text { Esquema de } \\
\text { tratamento } \\
\text { (mg/Kg) }\end{array}$} & $\begin{array}{c}\text { Maduros } \\
\text { Ovos }\end{array}$ & \multicolumn{4}{c}{ Ovos Imaturos (\%) } & \multirow{2}{*}{$\begin{array}{c}\text { Alteração de } \\
\text { oograma }\end{array}$} \\
\cline { 3 - 6 } & & IV & III & II & I & \\
\hline Sem tratamento & 55,77 & 12,67 & 16 & 4,78 & 10,22 & Não \\
Controle PZQ & $91,59^{a}$ & $0,93^{a}$ & $0,93^{a}$ & $0,93^{a}$ & $5,6^{a}$ & Sim \\
Dose Única 50 & $65,24^{b}$ & $9,38^{b}$ & $3,2^{a b}$ & $7,25^{b}$ & 14,92 & Sim \\
Dose Única 100 & $54,46^{b}$ & $6,02^{a b}$ & $7,71^{b}$ & $11,08^{b}$ & $20,72^{b}$ & Sim \\
Duas Doses 50 & $59,04^{b}$ & $8,04^{b}$ & 5,02 & $9,04^{b}$ & $18,84^{b}$ & Sim \\
Duas Doses 100 & $65,91^{b}$ & $9,58^{b}$ & $7,6^{a b}$ & 3,94 & 12,96 & Sim \\
\hline
\end{tabular}

a: Diferença significativa em relação ao grupo controle não tratados $(p<0,05)$;

$b$ : Diferença significativa em relação ao grupo controle $P Z Q(p<0,05)$.

Fonte: elaboração própria.

De acordo com os dados supracitados, nota-se que para as duas drogas, em todos os esquemas terapêuticos, assim como ocorre no grupo controle PZQ, ocorreu a ausência de pelo menos um dos estágios imaturos, sugerindo que tais tratamentos interferem, em algum grau, na cinética de desenvolvimento dos ovos. Para Katz (2008), após o tratamento, a ausência de qualquer um dos estágios dos ovos viáveis é indicação de que houve parada de postura e que, portanto, a droga tem atividade sobre S. mansoni.

Além disso, em todos os grupos experimentais, incluindo os grupos-controles, para as duas drogas, existe uma prevalência de ovos no estágio maduro, destacando-se uma diferença significativa entre os grupos-controles.

Adicionalmente, observou-se que, com exceção ao grupo controle sem tratamento, em todos os demais grupos experimentais ocorreu uma contagem inferior a 50 ovos viáveis por fragmento de intestino em pelo menos um animal. No grupo controle $\mathrm{PZQ}$, de modo especial, em nenhuma das lâminas chegou-se à contagem de 50 ovos, achando-se fragmentos com 34 ovos ou nenhum ovo. Esse fenômeno é facilmente assimilado uma vez em que se conhece a natureza esquistossomicida do praziquantel, que reduz drasticamente a quantidade de vermes adultos dias após o tratamento, e consequentemente a quantidade de ovos achados nos tecidos tende a ser menor. De modo semelhante, nos grupos tratados 
com LS26 ou LS29 ocorreu a contagem inferior a 50 ovos por fragmento em pelo menos um dos animais experimentados; por exemplo, no grupo LS29 100 em duas doses, cinco fragmentos tinham menos de 50 ovos.

Enfim, notou-se que ambas as drogas parecem interferir na cinética de desenvolvimento dos ovos uma vez que em todos os esquemas terapêuticos foi atribuído um oograma alterado. Tais resultados corroboram com os de redução da carga parasitária e com o aumento do deslocamento parcial dos vermes do mesentério, reforçando o caráter de drogas ativas, in vivo, contra vermes adultos de S. mansoni.

\subsubsection{Avaliação da peroxidação lipídica nas amostras de fígado}

A detecção da concentração de MDA utilizando o TBA pode ser feita através do "teste das substancias reativas com ácido tiobarbitúrico (SRATB)", um método bastante popular por ser simples e rápido, sendo capaz de fornecer informações sobre o grau de peroxidação lipídica nos tecidos (LIMA; ABDALLA, 2001).

Cunha (2008), ao investigar alterações bioquímicas em pacientes com esquistossomose aguda, identificou níveis elevados de MDA no plasma dos indivíduos acometidos por essa doença através de uma técnica semelhante à aplicada neste estudo. No modelo de esquistossomose experimental que estudamos, nas amostras de fígado não foram observadas diferenças significativas nos níveis de MDA entre grupos experimentais, com exceção ao grupo de animais tratados com LS29 (100 mg/Kg, em duas doses), onde detectou-se uma maior concentração de MDA se comparadas às concentrações encontradas nos grupos "Tratados PZQ" e "LS29 DU 100" (gráfico 7). 


\section{Gráfico 7 - Níveis de malondialdeído em homogenato de fígado de animais} submetidos à infecção com Schistosoma mansoni.

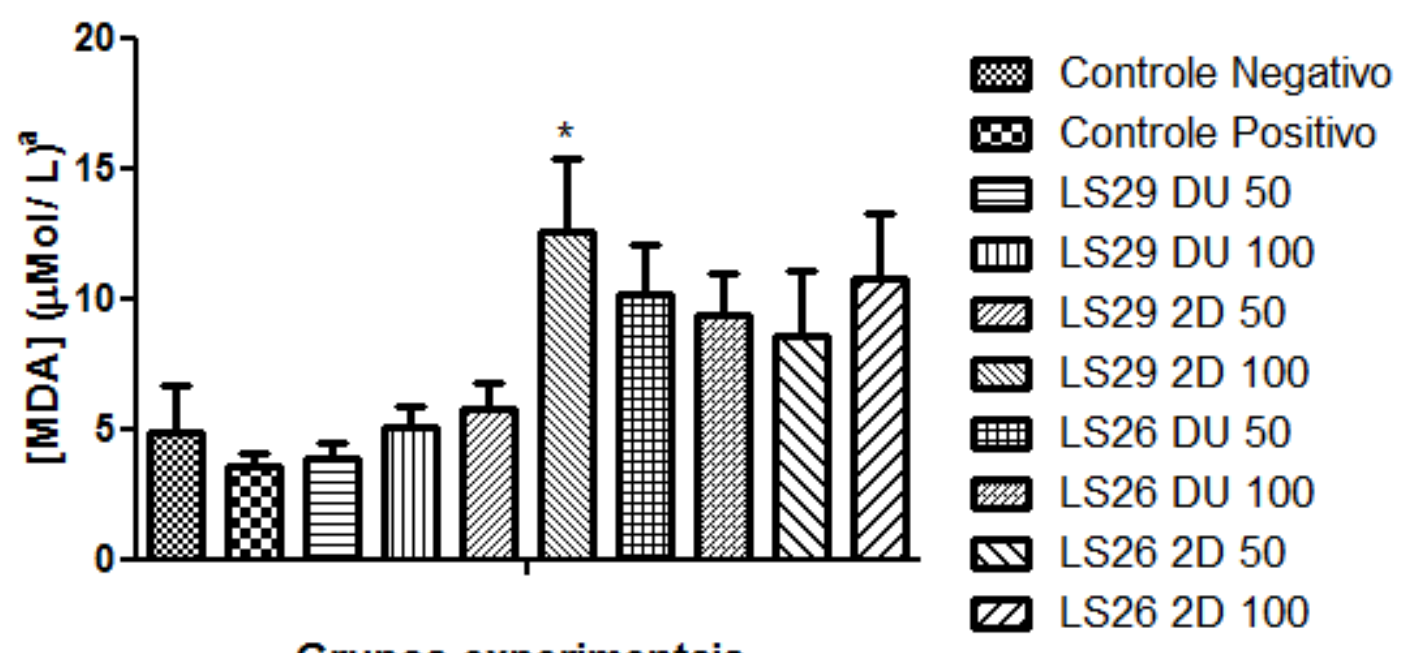

aMDA, Concentração de malondialdeído em micromols por litro. *representa aumento significativo $(p<0,05)$ da concentração de MDA quando comparado ao grupo Controle Positivo (ANOVA seguida de teste de Tuckey).

Fonte: elaboração própria.

O gráfico 7 ilustra os valores da concentração de MDA em micromols por litro de homogenato de fígado de todos os animais que foram submetidos à infecção com S. mansoni. Pode-se inferir que: quanto maior for a concentração, maior a formação do complexo TBA-MDA; logo, mais intensa foi a peroxidação lipídica. Assim, considerando os flavonoides LS26 e LS29 como possíveis agentes antioxidantes, agindo de forma teórica no combate aos radicais livres gerados no processo patológico da esquistossomose no fígado, era esperado uma redução da peroxidação lipídica nos animais tratados em comparação aos não tratados, fato que não foi observado com esse experimento.

Ainda, apesar de partirmos de um viés teórico interessante, os flavonoides em questão, assim como outros xenobióticos introduzidos em organismos complexos, podem ter sofrido metabolização e perdido estruturas como anéis aromáticos e duplas conjugadas capazes de sequestrar os radicais livres. 


\section{CONCLUSÃO}

As NTPDases de $S$. mansoni guardam homologia estrutural com a apirase de batata, sendo essa empregada no modelo in vitro de busca de inibidores para essa família de enzimas. Das auronas testadas nesse trabalho, apenas LS26 apresentou atividade inibitória das atividades ATPásicas e ADPásicas.

Adicionalmente, através do uso das sondas fluorescentes, foi possível evidenciar a presença intensificada de autofagossomos e poros na membrada dos vermes expostos às drogas LS23, LS26 e LS29, o que pode sugerir um possível local de ação esquistossomicida dessas drogas.

Os resultados in vivo sugeriram que as drogas LS26 e LS29 foram efetivamente esquistossomicidas pois reduziram significativamente a carga global parasitária. Além disso, promoveram o deslocamento parcial dos vermes das veias mesentéricas para os vasos hepáticos e foram capazes de interferir na cinética de desenvolvimento dos ovos, uma vez que em todos os esquemas terapêuticos foi observado um oograma alterado.

Apesar das auronas atuarem como agentes antioxidantes, os compostos LS26 e LS29 administrados por via oral experimentalmente infectados não foram capazes de reduzir o nível de peroxidação lipídica no fígado.

Por fim, o conjunto de resultados sugere que as drogas LS26 e LS29 são fortes candidatas às novas drogas esquistossomicidas, destacando-se a necessidade de se investigar seus perfis farmacocinético e farmacodinâmico de forma mais detalhada, além de se pensar estratégias no campo da farmacotécnica para desenvolvimento de uma fórmula farmacêutica estável, segura e eficaz. 


\section{REFERÊNCIAS}

AL-ADHAMI, B. H. et al. The role of acidic organelles in the development of schistosomula of Schistosoma mansoni and their response to signalling molecules.

Parasitology. V. 130, p. 309-322, 2005.

ARAÚJO, N. et al. Suscetibilidade aos agentes quimioterápicos de isolados de Schistossoma mansoni oriundos de pacientes tratados com oxaminiquine e praziquantel e não curados. Revista da Sociedade Brasileira de Medicina Tropical, São Paulo, v. 29, n. 5, p. 467-476, 1996.

ASAI, T. et al. High correlation in antibody titers between Sabin-Feldman dye test and an enzyme kinked immunosorbent assay detecting immunoglobulin $\mathrm{G}$ antibodies to the nucleoside triphosphate hydrolase of Toxoplasma gondii. Journal of Clinical Microbiology, v. 30, p. 1291-3, 1992.

BANDGAR, B. P. et al. Syntheses and biological evaluation of sample methoxylated chalcones as anticancer, anti-inflammatory and antioxidant agents. Bioorganic and \& Medicinal Chemistry, v. 18, p. 1364-1370, 2010.

BARROS, F. S. et al. Ectonucleotide diphosphohydrolase activities in Entamoeba histolytica. Archives of Biochemistry and Biophysics, v. 375, p. 304-314, 2000.

BHARDWAJ, R.; SKELLY, P. J. Purinergic signaling and immune modulation at the schistosome surface? Trends in Parasitology, v. 25, n. 6, p. 256-60, 2009.

BHASKER, N; REDDY, M. K. Synthesis and characterization of new series of prenyloxy chalcones, prenyloxy aurones and screening for anti-bacterial activity. International Journal of Research in Pharmaceutical and Biomedical Sciences, v. 2, p. 1266-1272, 2011.

BOUMENDJEL, A. Aurones: A subclass of flavones with promising biological potential. Current Medicinal Chemistry, v. 10, p. 2621-2630, 2003.

BRASIL. Ministério da Saúde. Secretaria de Ciência, Tecnologia e Insumos Estratégicos. Departamento de Ciência e Tecnologia. Doenças negligenciadas: Estratégias do Ministério da Saúde. Brasília: Ministério da Saúde, 2010.

BRASIL. Ministério da Saúde. Secretaria de Vigilância em Saúde. Vigilância da esquistossomose mansoni: diretrizes técnicas. 4. ed. Brasília-DF, 2014. Disponível em:< http://bvsms.saude.gov.br/bvs/publicacoes/vigilancia_esquistossome_mansoni_diretr izes_tecnicas.pdf>. Acesso em: 20 set. 2017.

BRASIL. Ministério da Saúde. Portal da Saúde. Saúde de A a Z: Esquistossomose. Disponível em:<http://portalms.saude.gov.br/saude-de-a-z/esquistossomose. Acesso em: 21 ago. 2018. 
BRASIL. Ministério da Saúde. Sistema de Informação do Programa de Vigilância e Controle da Esquistossomose - SIPCE, 2012. Disponível em:<

http://tabnet.datasus.gov.br/csv/A205318186_213_80_84.htm>. Acesso em: 20 set. 2017.

BRASIL. Ministério da Saúde. Secretaria de Ciência, Tecnologia e Insumos Estratégicos. Departamento de Assistência Farmacêutica e Insumos Estratégicos. Relação Nacional de Medicamentos Essenciais: RENAME 2017, Brasília: Ministério da Saúde, 2017.

CARVALHO, O. S; COELHO, P. M. Z.; LENZI, H. L. Schistosoma mansoni \& Esquistossomose: uma visão multidisciplinar. Rio de Janeiro: Fiocruz, 2008.

$\mathrm{CHENG}, \mathrm{H}$. et al. Design, synthesis and discovery of 5-hydroxyaurone derivatives as growth inhibitors against HUVEC and some cancer cell lines. European Journal of Medicinal Chemistry, v. 45, p. 5950-5957, 2010.

COIMBRA, E. S. et al. Characterization and cytochemical localization of an ATP diphosphohydrolase from Leishmania amazonensis promastigote. Parasitology, v. 124, p. 137-143, 2002.

CIOLI, D; PICA-MATTOCCIA, L; ARCHER, S. Drug resistance in schistosomes. Parasitology Today, v.9, n.5, p.162-166, 1993.

CUNHA, G. M. M. Alterações nas concentrações das SRAT, conteúdo de GSH e atividade CAT em pacientes com esquistossomose aguda. Dissertação de mestrado. Universidade Federal do Rio Grande do Norte, Natal-RN, 2008.

DETSI, A. et al. Natural and synthetic 20 -hydroxy-chalcones and aurones: Synthesis, characterization and evaluation of the antioxidant and soybean lipoxygenase inhibitory activity. Bioorganic \& Medicinal Chemistry, v. 17, p.80738085, 2009.

DOENHOFF, M. J; CIOLI, D; UTZINGER, J. Praziquantel: mechanisms of action, resistance and new derivatives for schistosomiasis. Current Opinion in Infectious Diseases, v. 21, n. 6, p.659-667, 2008.

DNDi - Drugs for Neglected Diseases initiative. Disponível em:< https://www.dndi.org/diseases-projects/\#ftn1>. Acesso em: 10 abr. 2017.

EMBOUBOU, C. et al. Circulating markers of oxidative stress and liver fribosis in Sudanese subjects at risk of schistosomiasis and hepatitis. Acta Tropica, v. 94, p.99-106, 2005.

FARIA-PINTO, P. et al. ATP diphosphohydrolase from Schistosoma mansoni egg: characterization of a new antigen. Parasitology, v. 129, p. 51-57, 2004.

FARIA-PINTO, P. Mapeamento dos domínios antigênicos compartilhados entre a apirase de batata e as isoformas de ATP difosfohidrolase de Schistosoma 
mansoni. Tese de doutorado. Programa de Pós-graduação em Ciências da Saúde Centro de Pesquisas René Rachou (FIOCRUZ), Belo Horizonte-MG, 2008.

FIETTO, J. L. et al. Characterization and immunolocalization of an NTP diphosphohydrolase of Trypanosoma cruzi. Biochemical and Biophysical Research Communication, v. 316, p. 454-460, 2004.

FREITAS, L. A. R. et al. Esquistossomose mansonica. In: FILHO, G. B. (Org.). Bogliolo. Patologia. 9 ed. Rio de Janeiro: Guanabara Koogan, 2016. p. 1924.

HANDA, M.; GUIDOTTI, G. Purification and cloning of a soluble ATPdiphosphohydrolase (apirase) from potato tubers (Solanum tuberosum). Biochem Biophys Res Commun, v. 218, n. 3, p 916-23, 1996.

HUANG, H. Q. et al. A new aurone and other phenolic constituents from Veratum schindleri Loes. f. Biochemical Systematics and Ecology, v. 36, p. 590-592, 2008.

HUBINGER, S. Z. Estudo farmacognóstico e desenvolvimento de fitocosmético de ação antioxidante dos frutos de Dimorphandra mollis benth. (LEGUMINOSAE- CAESALPINIOIDEAE). Dissertação de mestrado. Universidade Estadual Paulista, Araraquara-SP, 2009.

HUNT, P. et al. Neglected diseases: a human rights analysis. Geneva: TDR/World Health Organization, 2007.

JEREMIAS, W. J. Aspectos adaptativos de Schistosoma mansoni na fase esquistossômulo: abordagem in vivo e in vitro.Tese de doutorado. Programa de Pós-Graduação em Ciências da Saúde do Centro de Pesquisas René Rachou. Área de concentração: Doenças Infecciosas e Parasitárias. Fundação Oswaldo Cruz, Belo Horizonte-MG, 2015.

KATZ, N. Terapêutica Experimental da Esquistossomose Mansoni. In: CARVALHO, O. S. (Org.). Schistosoma mansoni e esquistossomose: uma visão multidisciplinar. Rio de Janeiro: Fiocruz, 2008.

KAYSER, O.; KIDERLEN, A. F.; BRUN, R. In vitro activity of aurones against Plasmodium falciparum strains K1 and NF54. Planta Medica, p. 718, 2001.

KINDHAUSER, M. et al. Communicable diseases 2002: Global defence against the infectious disease threat. Geneva: World Health Organization, 2003.

LEVANO-GARCIA, J. et al. Characterization of Schistosoma mansoni ATPDase2 gene, a novel apyrase family member. Biochemical and Biophysical Research Communication, v. 352, p. 384-389, 2007.

LIMA, S. É; ABDALLA, D. S. P. Peroxidação lipídica: mecanismos e avaliação em amostras biológicas. Revista Brasileira de Ciências Farmacêuticas, v. 37, p. 293303, 2001. 
LOWRY, O. H. et al. Protein measurement with the Folin phenol reagent. The Journal of Biological Chemistry. v. 193, n. 1, p. 265-275, 1951.

MUSCHIETTI, L. V.; MARTINO, V. S. Atividades biológicas dos flavonóides naturais. In: YUNES, R.A.; CECHINEL FILHO, V. Química de produtos naturais, novos fármacos e a moderna farmacognosia. Itajaí: Univali, p. 183-207, 2007.

NAVAB, M. et al. The yin and yang of oxidation in the development of the fatty streak. A review based on the 1994 George Lyman Duff Memorial Lecture.

Arteriosclerosis, thrombosis, and vascular biology, v. 16, p. 831-842, 1996.

NELSON, D. L.; COX, M. M. Princípios de Bioquímica de Lehninger. 5. ed. Porto Alegre: Artmed, 2011.

PEDRIQUE et al. The drug and vaccine landscape for neglected diseases (20002011): a systematic assessment. The Lancet, v. 1, p. e371-e379, 2013.

PELLEGRINO, J. et al. New approach to the screening of drugs in experimental schistosomiasis mansoni in mice. The American Journal of Tropical Medicine and Hygiene, v. 11, p. 201-215, 1962.

PELLEGRINO, J; KATZ, N. Experimental chemotherapy of Schistosomiasis mansoni. Advances in Parasitology, v. 6, p. 233-290, 1968.

PELLEGRINO, J.; SIQUEIRA, A. F. Técnica de perfusão para colheita de Schistosoma mansoni em cobaios. Revista Brasileira de Malariologia e Doenças Tropicais. v.8, p. 589-597, 1956.

PENIDO, L. O. M. et al. A new series of schistosomicide drugs, the alkylaminoalkanethiosulfuric acids, partially inhibit the activity of Schistosoma mansoni ATP diphosphohydrolase. European Journal of Pharmacology, v. 570, n. 1-3, p. 10-7, 2007.

RAHMAN, A. U. et al. Two new aurones from marine brown alga Spatoglossum variable. Chemical \& Pharmaceutical Bulletin, v. 49, p. 105-107, 2001.

REMME, J. H. et al. Strategic emphases for tropical diseases research: a TDR perspective. Trends in Parasitology, v.18, p. 421-426, 2002.

ROSS, A. G. P. et a. A new global strategy for the elimination of schistosomiasis. International Journal of Infectious Diseases. v. 54, p. 130-137, 2016.

ROUSSAKI, M. et al. Aurones: a Promising Heterocyclo Scaffold for the Development of Potent Antileshmanial Agents. International Jornal of Medicinal Chemistry, v. 2012, p. 1-8, 2012.

SILVEIRA, L. S. Síntese e avaliação da atividade esquistossomicida de chalconas e auronas frente a vermes adultos de Schistossoma mansoni.

Dissertação de mestrado. Universidade Federal de Juiz de Fora, Juiz de Fora-MG, 2013. 
SIMÕES, C.M.O. et al. Farmacognosia: da planta ao medicamento. Editora da UFSC, Florianópolis: Santa Catarina, 2010.

SOUARD, F. et al. 1-azaaurones derived from the naturally occurring aurones as potential antimalarial drugs. Bioorganic and Medicinal Chemistry, v. 18, p. 5724$5731,2010$.

SOUZA, F. P. C. et al. Esquistossomose mansônica: aspectos gerais, imunologia, patogênese e história natural. Revista da Sociedade Brasileira de Clínica Médica, v. 9, n. 4, p. 300-7, 2011. Disponível em:

<http://files.bvs.br/upload/S/16791010/2011/v9n4/a2190 s. Acesso em: 10 ago. 2017.

TAUSSKY, H. M; SHORR, E. A microcolorimetric method for the determination of inorganic phosphorus. The Journal of Biological Chemistry. v. 202, n. 2, p. 675685, 1953.

VASCONCELOS, E. G. et al. Characterization and localization of na ATPdiphoshohydrolase on the external surface of the tegument of Schistosoma mansoni. Molecular and Biochemistry Parasitology, v. 58, n. 2, p. 205-214, 1993.

VASCOCELOS, E. G. et al. Partial purification and immunohistochemical localization of ATP diphosphohydrolase from Schistosoma mansoni. Immunological crossreactivities with potato apyrase and Toxoplasma gondii nucleoside triphosphate hydrolase. The Journal of Biological Chemistry, v. 271, n. 36, p. 22139-45, 1996.

VASCONCELOS, E. G. et al. "The ATP-diphosphohydrolase of Schistosoma mansoni: Ecto-localization and possible roles in host-parasite interactions" In: PLESNER, L; KIRLEY, T. L; KNOWLES, A. F. (Eds). Ecto-ATPases: Recent Progress on Structure and Function. Plenum Publishing Corporation, p. 221-226, 1997.

VENKATESWARLU, S. et al. Synthesis, structural revision and biological activities of 4'-chloroaurone, a metabolite of marine brown alga Spatoglossum variabile.

Tetrahedron, v. 63. p. 6909-6914, 2007.

WORLD HEALTH ORGANIZATION (WHO). Health Topics: Tropical Diseases. Disponível em:<http://www.who.int/topics/tropical diseases/en/>. Acesso em: 10 jan., 2017.

ZIMMERMANN, H; ZEBISCH, M; STRATER, N. Cellular function and molecular structure of ecto-nucleotidases. Purinergic Signal, v. 8, n. 3, p. 437-502, 2012. 